Review

\title{
Retinoic Acid and the Development of the Endoderm
}

\author{
Gregory M. Kelly ${ }^{1,3,4}$ and Thomas A. Drysdale ${ }^{1,2,3,4, *}$
}

1 Department of Paediatrics, Western University, 800 Commissioners Road East, London, ON N6A 5W9, Canada

2 Department of Physiology and Pharmacology, Western University, London, ON N6A 5C1, Canada

3 Department of Biology, Western University, London, ON N6A 5B7, Canada

4 Children's Health Research Institute, 800 Commissioners Road East, London, ON N6C 2V5, Canada

* Author to whom correspondence should be addressed; E-Mail: tadrysda@uwo.ca; Tel.: +1-519-685-8500 (ext. 55072).

Academic Editor: Andy Wessels

Received: 7 March 2015 / Accepted: 2 April 2015 / Published: 20 April 2015

\begin{abstract}
Retinoic acid (RA) is an important signaling molecule in the development of the endoderm and an important molecule in protocols used to generate endodermal cell types from stem cells. In this review, we describe the RA signaling pathway and its role in the patterning and specification of the extra embryonic endoderm and different endodermal organs. The formation of endoderm is an ancient evolutionary feature and RA signaling appears to have coevolved with the vertebrate lineage. Towards that end, we describe how RA participates in many regulatory networks required for the formation of extraembryonic structures as well as the organs of the embryo proper.
\end{abstract}

Keywords: retinoic acid; retinoids; endoderm; embryology; development; anterior-posterior axis; thyroid; lung; pancreas; extraembryonic endoderm

\section{Introduction}

Retinoic acid (RA) signaling is one of the fundamental regulatory pathways in the development of vertebrates with roles in the differentiation and patterning of lineages from all three germ layers $[1,2]$ 
including the endoderm, which is the subject of this review. A significant role for RA signaling in the development of endoderm might appear somewhat surprising because endoderm is a germ layer of all multi-layered embryos, whereas the RA signaling system has often been described as a signaling system that has arisen during chordate evolution $[3,4]$. There is now, however, evidence that homologues of enzymes and receptors necessary for RA signaling exist in different invertebrates [5-7], but it is still not clear as to whether or not these homologues function in an analogous manner. If in fact they have alternate functions, then retinoic acid signaling may be an adaption that occurred during evolution and unique to the chordates. Whatever the case, that Caenorhabditis and Drosophila do not have functional RA receptors would indicate that a functional endoderm does not require retinoic acid signaling. In addition, some urochordates appear to have lost the fundamental machinery necessary for RA signaling, yet still produce a functional endoderm [8]. A lack of retinoic acid signaling does not alter initial endoderm formation in zebrafish [9], Xenopus [10] or the initial endoderm patterning in chick [11]. That said, the endoderm in vertebrates has evolved a number of novel innovations, including the generation of unique endoderm-derived organs and the formation of an extraembryonic endoderm. It is in the development of these novel endoderm features that retinoic acid signaling is clearly required.

\section{What is Endoderm?}

Endoderm is the inner germ layer in both diploblastic and triploblastic embryos. In general, it forms an internal epithelial tube that represents the digestive tract. This primitive feeding feature, coupled with recent analysis of tissue-specific gene expression in diverse organisms, suggests that the endoderm is the original germ layer [12]. In vertebrates, that tube has a series of lateral extensions, which give rise to organs including the thyroid gland, thymus, lungs, liver, and pancreas (Figure 1). Ectoderm, the outer germ layer of the embryo, will form the skin, nervous system and the specialized neural crest cells. Mesoderm, the layer that comes to lie between the endoderm and mesoderm forms a variety of organs including the cardiovascular system, muscles and kidneys. Both molecular and fate mapping evidence suggests that the endoderm and mesoderm actually arise from a common progenitor termed the mesendoderm [13]. Key transcription factors for mesoderm and endoderm are expressed in the same cells in zebrafish [14,15] and Xenopus [16] and the fate map of the Caenorhabiditis embryo shows that one blastomere gives rise to both lineages [17]. However, given the ancient origin of the endoderm relative to mesoderm [12], it is likely that the common progenitor represents a derived developmental strategy and, although widespread, is not universal [18].

Endoderm differentiation requires integration of multiple signaling events early in development. Nodal, a member of the TGF $\beta$ superfamily of signaling molecules is essential for the development of the mesendoderm [19] and varying levels of Nodal signaling are important not only in the segregation of the endoderm from mesoderm [20], but also in patterning the extraembryonic endoderm [21,22] as described below. Nodal signaling subsequently regulates the expression of several transcription factors that represent a conserved network essential for differentiation of the endoderm including members of the Forkhead, Gata, Mixer, Sox, and PouV transcription factor families [13,23,24]. Interestingly, metabolism of maternal RA by Cyp26 enzymes is required to limit the expression of Nodal in the mouse, thereby preventing duplication of the body axis, but it is unclear as to whether or not this RA plays any role in mesendoderm differentiation [25]. That Wnt signaling is required for the maintenance 
of Nodal expression [26] and Nodal is in turn required for the maintenance of Wnt3 expression [27] would indicate complex interactions are needed to regulate Nodal levels that are critical for endoderm differentiation. Although RA signaling is required for many early developmental events, there is no evidence that it plays a role in endodermal differentiation in vivo. This is surprising as RA is routinely used to generate endoderm from several undifferentiated embryonal carcinoma and embryonic stem cell lines [28-31]. Where RA does appear to play important roles is in the patterning of the endoderm once it is differentiated and in the differentiation of specific endodermal organs.

$\underline{\text { Dorsal }}$

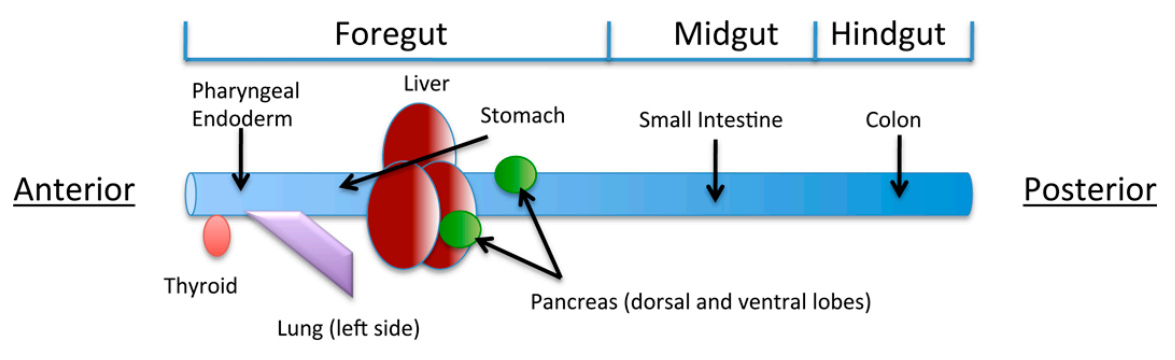

Ventral

Figure 1. Derivatives of the endoderm form along the gut tube in a precise anterior to posterior order. The gut is first divided into broad regions of foregut, midgut, and hindgut. Subsequently, the gut is further subdivided so that individual organ types form in a precise order with the thyroid being the most posterior. Retinoic acid (RA) is essential for the development of most organ primordial posterior to the thyroid with the strongest requirement being in the dorsal anterior derivatives such as dorsal pancreas and lung. The pancreas is formed from a dorsal and ventral bud. Retinoic acid is required for dorsal pancreatic bud formation but not the ventral bud in most organisms.

\section{Retinoic Acid Signaling}

As cell signaling pathways go, that involving RA is essentially quite simple although, as with most biological systems, it is more complicated than it first appears. Retinoic acid is a metabolite of vitamin A and a small molecule, with a molecular weight of 300 daltons. It is highly lipophilic, enabling it to readily pass through the plasma membrane and move to the nucleus, where it binds to heterodimers of nuclear receptors belonging to one of two small families: the RA receptors (RAR $\alpha, \operatorname{RAR} \beta$, and $\operatorname{RAR} \gamma$ ) and the retinoid $\mathrm{X}$ receptors $(\mathrm{RXR} \alpha, \mathrm{RXR} \beta$, and $\mathrm{RXR} \gamma)[2,32]$. When RA is absent, RAR/RXR heterodimers bind specific DNA binding sites within the genome where they act to recruit repressive complexes that inhibit transcription [33]. In the presence of RA, however, the repressive complex bound to the receptor is exchanged for an activating complex and transcription at the target site is promoted. Thus, the RARs are considered ligand-activated transcription factors. As the receptors are already present on many target genes, this makes RA the limiting factor in deciding whether or not target genes are activated. 


\subsection{Generating Retinoic Acid}

Vitamin A (retinol) is taken up in the maternal diet and is supplied to the egg during oogenesis. The first step in the formation of RA is the conversion of retinol to retinaldehyde. Different members of the alcohol dehydrogenase or retinol dehydrogenase families catalyze this oxidation step. Of these enzymes, the most important for early embryogenesis is Rdh10. Mice lacking this enzyme have severe developmental defects and die at about E10.5 [34-36]. The strong requirement for Rdh10 in RA signaling is also conserved in Xenopus [37]. This step in RA synthesis is strongly regulated by a negative feedback loop, where the addition of RA causes a down regulation in Rdh10 expression and a concomitant up regulation of Dhrs3a, an enzyme that catalyzes the reverse reaction generating retinol from retinaldehyde [38].

The subsequent generation and maintenance of all-trans RA levels is critical and the enzymes that both generate and subsequently catalyze it are also subject to tightly regulated feedback loops [2,39]. Indeed, RA teratogenicity is, in part, explained by a down regulation of RA signaling caused by the exposure to high levels of RA [40]. Several enzymes are responsible for the conversion of retinaldehyde to all-trans RA, primarily members of the Raldh family, with each member having unique developmental expression patterns [41]. Based on the phenotypes of mice lacking individual genes within the Raldh family, Aldh1a2 is the main enzyme responsible for RA production during early development. In mice, the loss of Aldhla2 results in dramatic embryonic phenotypes with disruptions in multiple organs and lethality at E9.5-10.5 [42-45]. Interestingly, the loss of Aldh1al in mice does not result in any observable phenotype [46], while the loss of Aldhla3 results in defects in the ocular and nasal regions [47] as well as neuronal differentiation in the brain [48].

There are alternative mechanisms for generating RA, including one that uses $\beta$-carotene as a substrate [49-52]. Unfortunately, the roles for these alternative pathways in development have not been fully explored. Importantly for this review, it appears that Aldh1a2 is the sole source of RA generation in the endoderm and the surrounding lateral plate mesoderm, at least until e9.5 in mouse [53].

Despite the fact that RA signaling activity appears to be primarily controlled by the levels of the ligand, the importance of catabolism is often overlooked [54]. The primary catabolic enzymes include members of the cytochrome p450 family, specifically Cyp26A1, Cyp26B1 and Cyp26C1 [55]. Loss of Cyp26 enzymes in zebrafish and mice results in severe phenotypes with caudal truncations, homeotic transformations and embryonic lethality [25,56-58]. It is interesting to note many of these phenotypes are very similar to the phenotype caused by the administration of teratogenic doses of RA [59].

\subsection{Movement of Retinoic Acid}

Once generated, RA moves freely between cells, an activity that made it a proposed diffusible morphogen patterning limb development [60]. Specific cellular binding proteins exist that are thought to solubilize RA in order to aid in its intracellular transport through the aqueous cytoplasm to the nucleus and for facilitating its degradation by Cyp26A1. The role for the cellular retinoic acid-binding proteins (CRABPs and CRBP) is somewhat less clear. Despite recent work suggesting that the presence of these RA-binding proteins allows for greater fine-tuning of the RA signal [61], it is clear from the 
knockouts in mice that CRABPs and CRBP are not essential proteins $[62,63]$. Thus, the requirement for these binding proteins in intercellular signaling by RA is not well understood, although a role for CRABPs in hindbrain patterning in zebrafish, presumably through altering the dynamics of the retinoic acid response, has been demonstrated [61].

Movement across a membrane appears to be facilitated in some cell contexts by Stra6, a membrane bound protein that can interact with retinol binding protein, which binds retinol in the serum. The loss of Stra6 in the mouse has only a modest effect on the levels of RA signaling in most tissues, with the exception of the eye [64]. Here, the presence of Stra6 is necessary for both normal morphology and a proper visual response [65]. It is interesting to note that human mutations in STRA6 are associated with multiple developmental defects including, in some patients, lung hypoplasia $[66,67]$.

\subsection{Interaction with DNA}

RARs bind to DNA as a heterodimer with an RXR. As both receptors have essentially the same DNA recognition site (RGKTCA), a canonical retinoic acid response element (RARE) is usually two direct repeats of the recognition sequence, separated by a spacer region of variable length [68]. The use of chromatin immunoprecipitation (ChIP), however, with antibodies against RARs has demonstrated a much greater diversity of RAREs than previously appreciated, including direct repeats with no spacer [69]. There is also evidence that inverted repeats with no spacer can also the target for RARs [69]. ChIP results also suggest that RA bound to receptors already on the promoter of target genes may not be representative of all of the potential targets. For instance, RAR-DNA interactions appear after the addition of RA [70], suggesting that receptors lacking RA are not necessarily bound to DNA or that unbound receptors do not immunoprecipitate well. In addition, RAR phosphorylation has demonstrated the importance in regulating the activity of the receptor [71,72]. Specifically, deleting an RAR $\gamma 2$ in mouse ES cells and replacing it with the same receptor, but with mutated phospho-acceptor sites, demonstrated that phosphorylation was necessary for differentiation of these cells into neurons.

In addition to the targeting based on binding to known RAREs, the specificity of binding is also regulated by interactions of other transcription factors and the epigenetic landscape around the RARE. Indeed, the cell specificity of the response to RA signaling is probably due to interactions with different regulatory proteins $[73,74]$. For example, fibroblasts and embryonic stem cells show clear differences in binding sites for RARs [73] as do embryonic stem cells and differentiated neurons [70]. Work in breast cancer cell lines has identified FoxA1 and GATA3 as potential tissue-specific co-regulators [75] and given the complexity of RA signaling in different cell types. The differing epigenetic signature of different cell types will also regulate where RARs may bind or regulate their activity levels [76]. Defining these cell-specific mechanisms for defining RA targets in different cells will be an important avenue for future research.

\section{The Role of Retinoic Acid in Anterior-Posterior Patterning of the Endoderm}

The initial steps in anterior-posterior patterning of the endoderm is started by a combination of Wnt, Fgf, and BMP signaling at the posterior end of the endoderm [13]. Wnt antagonism at the anterior end counteracts this signal, setting up an initial broad pattern of transcription factor expression. Hhex and Sox2 expression marks the presumptive foregut, $P d x 1$ the midgut, and $C d x$ expression the hindgut [13]. 
Although the treatment of embryos with RA or RA antagonists near gastrulation can alter the boundaries of early endoderm, as shown by changes to pancreatic differentiation $[9,10,77]$, it is not clear as to what the RA is affecting at these early stages.

Studies of RA signaling in endoderm development has largely concentrated on its role in the differentiation and growth of particular endodermal organs and have demonstrated that RA is essential for the normal development of almost all of them. However, before organogenesis, RA plays an essential role in the anterior-posterior patterning of the endoderm, and it is clear that the requirement for RA for different organ systems differ depending approximately on their position along this axis [11]. However, RA does not act in a strictly anterior-posterior gradient. Based on the expression pattern of Aldhla2 or of reporters of RA signaling, the highest regions of RA signaling appears to be the middle of the embryo, with the head and tail regions having little or no signaling activity (Figure 2). In Xenopus, this signaling also appears to be higher on the dorsal side [78,79]. This dorsal, middle region corresponds approximately to where more anterior organs, such as the dorsal pancreatic bud and lung that absolutely require RA are positioned. This requirement is not as crucial for the more posterior organs such as liver and ventral pancreatic bud. Interestingly, the thyroid, which is the most anterior organ derivative, must develop in the absence of RA $[11,80]$. Thus, the degree of requirement for RA in specific endodermal organs would appear to correspond to the levels of RA at a particular point along the anterior-posterior axis. Whether or not RA is in a gradient along that axis is tenuous, but the sensitivity of different regions to antagonists and the non-overlapping expression of Aldhla2 and Cyp26 suggest that a graded distribution is likely [11]. What is clear is that RA generates anterior-posterior patterning in the developing neural tube $[81,82]$ and in the mesoderm [83].

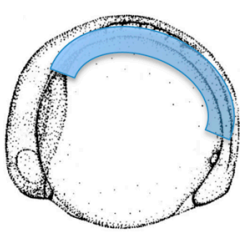

Zebrafish

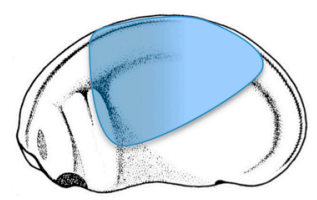

Xenopus

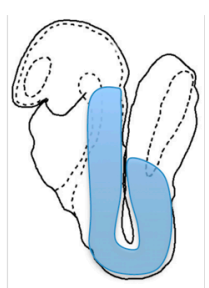

Mouse

Figure 2. Retinoic acid activity varies along the anterior-posterior axis but does not form a precise gradient along the entire axis. Using either Aldh1a2 expression or reporters of RA activity, the regions showing RA activity (shown in light blue overlapping an embryo schematic) are roughly in the middle of the embryo with notable absence of signaling at the most anterior and posterior ends of the embryo.

The requirement for RA in patterning all three germ layers leads to a key question in anterior-posterior patterning of the endoderm. The overlying lateral plate mesoderm helps to define the anterior-posterior pattern of the underlying endoderm [77,84] and although boundaries of gene expression domains within the overlying lateral plate mesoderm are quite broad, they are partially defined by RA $[85,86]$. However, the boundaries for the developing endodermal organs are considerably smaller. One of the lateral plate mesoderm domains can be outlined by the expression of foxF1, a forkhead family transcription factor whose expression domain overlies the dorso-anterior endoderm $[85,87]$. The foxF1 expression domain can be shifted by altering RA signaling [85] and loss 
of foxF1 results in gut tube defects [87]. The defects, in addition to patterning, are mainly attributed to the inability of the lateral plate mesoderm to adequately surround the developing endoderm. Thus to generate the endodermal pattern, it is difficult to determine whether RA acts directly on the endoderm, indirectly on the overlying mesoderm, or a combination of both. Although studies of lung development support the latter [88], further investigation is needed with other endodermal organs to fully appreciate the roles for RA signaling in individual germ layers that are needed to generate the anterior-posterior pattern.

\section{Role of Retinoic acid in Individual Organ Systems}

\subsection{Retinoic Acid and the Thyroid}

The thyroid is the most anterior of the endodermal organs and RA does not appear to play a role in its specification and differentiation. Reporters of RA activity do not show activity in the early mouse thyroid [88] and in the chick it develops in the absence of retinoic acid [11]. In Xenopus, the presence of RA actually causes the thyroid primordium to acquire characteristics of the lung, including the expression of surfactant protein genes [80]. That in both chick and Xenopus the expression of Hex in the thyroid is suppressed by the presence of RA, while expression in the liver is unchanged, would suggest that RA is suppressing the very early steps in thyroid differentiation $[11,80]$.

\subsection{Retinoic Acid and the Anterior Foregut}

The dependency on RA signaling becomes apparent as one moves posterior along the gut tube from the thyroid. The remainder of the foregut, immediately posterior to the thyroid, is a site of active RA signaling [89], and mice that lack Raldh2 die at about E10.5, prior to significant development of the foregut [42]. However, if the mothers are provided with exogenous RA, the lethality is partially rescued allowing for analysis of later foregut development. With only partial rescue or timed use of RA antagonists, such that lung development is initiated, the foregut and trachea are not well separated [89-91]. These results would indicate that RA is essential for maturation or morphogenesis in the anterior foregut.

\subsection{Retinoic Acid and the Pharynx}

Pharyngeal pouches are a complex tissue that is formed from components of all three germ layers and through interactions with the adjacent migrating neural crest. The pharyngeal endoderm, which contributes to the pouches arises between the thyroid and lung [92], is important in craniofacial development and is disrupted by either excess or reduced RA signaling [93]. Reduced signaling causes a decrease in the number of pharyngeal pouches [94-96] due to a loss of branchial arches 3 through 6 [97]. In contrast, excess RA causes defects in the first two branchial arches [98]. Given the complex development of this region, it has been difficult to determine which cell types in the pharynx require RA. Experiments in a variety of animals have demonstrated that there are also roles for RA in patterning the migrating neural crest and signaling affects its development [94-96,98]. However, timed treatments with antagonists that do not disrupt the neural crest still cause pharyngeal arch defects and 
direct changes in the expression of key endoderm genes, which would suggest that the endoderm is a key target of RA signaling [99].

Interactions between the neural crest and the pharyngeal endoderm result in a series of pouches that give rise to specialized endocrine glands including the thyroid (discussed above), parathyroid, thymus and the ultimobranchial body [100]. Which of these glands form, and which pharyngeal arch they are associated with, varies between phylogenetic groups and given that altering RA signaling alters arch patterning, it is not surprising that RA is related to these endocrine glands. Exogenous RA causes defects in the development of the thymus [101] and loss of retinoic acid signaling results in loss of both the parathyroid and thymus in mice [94].

Specification of the pharyngeal endoderm is not affected in zebrafish lacking RA, but the morphogenesis of the pouches is altered in a time dependent manner [95] and a point mutation in the zebrafish Aldhla2 gene called neckless results in a loss of pouch 3 and 4 [102]. This disruption in morphogenesis could be due to the altered migration of cells or segmentation of the pouches, with reduced segmentation causing the reduction in pouch number [95].

An attractive mechanism for how RA alters pharyngeal endoderm is by altering the expression pattern of the Hox genes. This family of transcription factors are essential for anterior posterior patterning in all germ layers and a specific role in the pharyngeal endoderm is well established [103]. RA is able to shift the expression pattern of Hox genes in the pharyngeal mesoderm $[11,94,98,99]$ and thus it is likely that RA can also regulate Hox expression in the pharyngeal endoderm [101]. Hox genes are known to vary in response to different concentrations of RA in many tissues and reporter assays for RA activity suggest that such a gradient of RA signaling exists in the pharyngeal endoderm $[53,99,104]$.

Tbx1 is an important transcription factor that is at least partially responsible for a human hereditary defect called DiGeorge syndrome that has characteristic defects in branchial arch morphogenesis. Aldhla2 and Tbxl genetically interact suggesting that elements of the RA signaling pathway could modify the DiGeorge syndrome phenotype [105]. Interestingly, in zebrafish and Xenopus the patterning within the pharynx may be altered, but the overall length of the region appears to remain unchanged when compared to the position of the lung and thyroid [80,95]. In amphioxus, the posterior limit of the pharynx is regulated by RA [106]. This apparent difference in a role for defining pharyngeal boundaries could be due either to evolutionary change during vertebrate evolution or simply differing techniques or timing in the interference of RA signaling.

\subsection{Retinoic Acid and the Lung}

Retinoic acid is critical to the development of the lung and in mice lacking Aldh1a2, lungs are absent [91,107]. This requirement for RA is evolutionarily conserved [11,80]. Initial specification appears to be unaffected based on the presence of $N k x 2.1$ expression in mice with blocked RA signaling, but without RA the lung primordium does not enlarge or express markers of differentiation [108]. After initial specification, RA is necessary for the integration of multiple signaling pathways needed for lung development. In the early endoderm, expression of Dickopf, a secreted inhibitor of the Wingless (Wnt) pathway, is suppressed by RA signaling and this suppression allows for local activation of Wnt signaling. Wnt signaling in turn promotes a critical Fgf10 signal from the 
adjacent mesoderm, which is necessary for the formation and growth of the lung bud [88]. At the same time, RA is necessary for the suppression of $\operatorname{Tgf} \beta$ signaling which facilitates Fgf10 signaling [109]. Simultaneous suppression of $\operatorname{Tgf} \beta$ signaling with antagonists while activating Wnt signaling will rescue lung bud formation in RA-deficient embryos [88]. That the same is true using beads soaked in Fgf [110] would strongly implicate this signaling network in promoting lung bud growth. Once the bud has grown, reduced RA signaling is needed for proper branching morphogenesis [111]. Given the tight regulation of Fgf signaling that is required for branching morphogenesis and the ability of RA to alter Fgf signaling, the observations that excess RA can disrupt branching is not surprising.

Several studies have noted that there are differences in the requirement for RA between the left and right lobe of the lung. When there is maternal supplementation of RA to developing embryos lacking Aldh1a2, lung buds outgrowth occurs, but the right side develops much better than the left. In embryos with deletion of multiple RARs [91], or in embryos from mothers on a vitamin A deficient diet [112], lung development is poor. In these animals there is an observable lung, but left lobe is lost and the right is usually hypoplastic. It is still not clear what the basis is for these phenotypes, but the promotion of asymmetric Fgf10 expression by RA [88] is potentially involved [111,113]. RA is also known to alter left-right coordination in the somites [114,115], but it is not clear as to whether or not these alterations to left-right patterning are linked. Recently, morpholino knockdown of Rargb in zebrafish has shown that that the RA receptor is necessary for liver and pancreas asymmetries as well as heart looping, another indicator of disrupted left-right asymmetry [116] and similar organ asymmetries occur in Xenopus gut morphogenesis [117]. How these asymmetries are manifested will be critical in understanding if these defects are at the level of individual organ morphogenesis or the result of something more general.

The role of RA in lung is clearly relevant to humans because mutations in the RA pathway are associated with syndromes linked to disrupted lung development, including PAGOD syndrome [118] and Matthew Wood syndrome that results from mutations in STRA6 [119]. Later roles for RA in lung maturation have also recently been demonstrated. Mice with dietary deficiencies in RA have increased smooth muscle differentiation in the fetal lung and this has implications for adult health in the mice. The RA deficient mice are hyper responsive to airway stimulation and the aberrant response persists regardless of the vitamin A status of the adult [120]. Thus, RA deficiencies in fetal life pose a significant health issue in the developing world, and have lifelong implications in terms of lung health in adults.

\subsection{Retinoic Acid and the Pancreas}

Retinoic acid is essential for normal pancreatic development. In mammalian embryos lacking Aldhla2, there are significant defects in the pancreas $[53,121]$. The requirement is also evolutionarily conserved. Studies on avian embryos revealed that signals from the lateral plate mesoderm drive endodermal cells to express $P d x I$ and thus take on a pancreatic fate [77]. Evidence suggests that RA may be that mesodermal signal required for initiation of $P d x 1$ expression $[9,122]$. Examination of mouse embryos carrying the RA-reporter transgene demonstrated that the pancreas is normally exposed to RA generated in the surrounding splanchnic lateral plate mesoderm [53]. In the mouse, expression of a dominant negative RAR in early pancreatic progenitors results in pancreatic agenesis 
also suggesting that the endoderm is a direct target of the RA signal promoting pancreatic development [123]. However, in chick explants, the effect of RA on promoting pancreas requires mesoderm suggesting that the RA is also acting on the mesoderm to drive pancreas differentiation [77]. Excess RA is able to drive an anterior expansion of the $P d x 1$ expression domain in zebrafish demonstrating that it is both necessary and sufficient for pancreas formation [124].

The pancreas is formed from two distinct buds, one dorsal and one ventral (Figure 1). In most organisms, the RA is required for development of the dorsal pancreas but that requirement does not extend to the ventral bud. In the mouse, the dorsal bud is lost in the mouse whereas the ventral bud is less affected. Treatment of Xenopus embryos with a retinoic acid receptor antagonist also shows a loss of the dorsal bud with no clear effect on the ventral bud [10,125]. Zebrafish embryos deficient in RA lack $P d x 1$ expression and consequently fail to develop any recognizable pancreas $[9,126]$. In the chick embryo, there is also loss of the both pancreatic buds with the loss of RA signaling [11]. In Xenopus, the dorsal bud develops into the endocrine pancreas whereas the ventral bud forms the exocrine pancreas.

Cyp26 expression limits the size of the pancreas and that expression is regulated by retinoic acid. This provides a model where retinoic acid is necessary for formation of the pancreas and also creates a negative feedback loop that regulates pancreas size [124]. Size regulation by RA in the mouse pancreas, in particular the $\beta$-cell and $\alpha$-cell mass, continues in the adult because vitamin A deficiency results in reduced mass that is subsequently restored when normal vitamin A levels are restored [127]

\subsection{Retinoic Acid and the Liver}

Retinoic acid is an important regulator of liver function and is essential for retinoic acid metabolism in the adult [128] and thus it is perhaps surprising that is apparently not essential for specification of the liver in model organisms, with the exception of zebrafish. Mice lacking Raldh2 still express key early liver transcription factors including Proxl and Hhex in the region of the embryo destined to form liver [53]. Xenopus and chick are similar to mammals as liver specification occurs in embryos lacking RA activity $[10,125]$. Exogenous RA can suppress Hhex expression in the chick and Xenopus thyroid $[11,80]$ and is also required for suppression of Hhex in the foregut endoderm between the thyroid and liver [11] but Hhex expression is not altered in the developing liver. In contrast, zebrafish embryos do require RA for liver specification and exogenous RA can cause ectopic liver formation [9]. Additional evidence for a role for RA in formation of the liver in zebrafish come from the suppression of Rbp4, a transporter of retinol in mammals, using splice-blocking morpholinos. Knockdown of Rbp 4 mRNA results in duplicated liver buds in the embryos. As Rbp4 is expressed in the yolk syncytial layer and not the endoderm, it is thought that this could be due to migratory changes in liver precursors [129]. Further evidence that Rbp4 is altering RA signaling in the Rbp4 morphants is needed before a complete understanding of this phenotype. In mouse and chick embryos lacking RA signaling, the liver is smaller suggesting that RA does promote liver growth in later development [11,89] but liver specification does not require RA in those embryos. 


\subsection{Retinoic Acid and the Stomach}

RA signaling is active in the endoderm that will give rise to the stomach [89]. In mice lacking Aldh1a2, the stomach does not form properly with the posterior stomach that gives rise to the glandular portion of the stomach being absent [89]. Those mice also have reduced expression of Hox genes that are essential for regionally subdividing the $C d x$ expression domain into specific hindgut regions [130]. Similar to the lung, expression of Fgfl0 in the stomach primordium requires RA signaling [89] which nicely corresponds to the requirement for Fgf10 signaling in the development of the glandular stomach [131].

\subsection{Retinoic acid and Posterior Endoderm}

In comparison to the more anterior regions of the gut, less is known about the relationship between RA and the patterning of the hindgut. The lack of information is largely due to the lethality of embryos lacking RA signaling prior to complete patterning of the posterior regions of the gut. In addition, there are relatively few markers of early hindgut that could be used to understand early patterning events. Addition of exogenous RA clearly disrupts the morphogenesis of this region with lack of looping and rotation [132,133] and differing levels of RA may even be important in the evolution of novel gut morphologies [134]. However, loss of RA signaling experiments in the hindgut, that can circumvent the earlier requirements for RA in other tissues, are necessary for an in depth understanding of the role of RA in this region.

$C d x$ genes are early markers of posterior endoderm and are essential for defining boundaries of the different gut domains including the intestine and duodenum [13]. It is clear that a variety of signaling pathways including sonic hedgehog, Fgf and Wnt are needed for $C d x$ expression and retinoic acid also plays a role in defining the $C d x$ expression [11]. Expression of dominant-negative RARs in the chick endoderm blocks $C d x$ expression suggesting that there is a direct requirement for RA signaling within the endoderm to maintain expression although treatment with RA antagonists does not always eliminate $C d x$ expression and addition of exogenous RA is not able to change the anterior boundary of $C d x$ expression [11]. Subdivision of the $C d x$ expression domain into different regions such as the large and small intestine correspond to expression of different members of the Hox gene cluster and it is likely that these are essential for defining the different fates as mutations in different Hox genes do cause gut malformations [130]. Given the essential role for RA in directly regulating the Hox gene cluster [104,135], it would appear likely that subdivision of the hindgut would be regulated, at least in part, by RA.

Although differentiation of the colon is apparently normal in mice lacking retinoic acid production, it is still an important component of colon physiology. In mice lacking Aldh1a1, Aldhla2, and Aldhla3, there is reduced density of enteric neurons and this reduced innervation results in reduced motility of the colon [136,137]. Interestingly, different deletion combinations of the retinaldehyde dehydrogenases had varying effects on different subtypes of enteric neurons suggesting that understanding the exact roles for RA in gut innervation will be complex. Direct effects on differentiation of the intestine have been observed in zebrafish embryos that lack either rdh11 (retinol dehydrogenase) or the adenomatous polyposis coli (APC) tumor suppressor gene. The requirement for both is 
explained by the observation that APC is required for the expression of $r d h l l$ and the loss of markers of intestinal differentiation seen when either are suppressed can be rescued by exogenous RA treatment [138]. Another retinol dehydrogenase, $r d h 1$, is also required for intestinal differentiation in zebrafish but its requirement is restricted to the anterior gut and this corresponds to its graded expression pattern with highest levels of expression in the anterior gut [139]. The link to the Hox genes is reinforced by this study as over expression of hoxc 8 , normally regulated by RA, was able to partially rescue the differentiation of the intestine.

The prostate gland is an out pouching of the posterior endoderm and RA is both necessary and sufficient for the formation of prostatic buds [140]. Fgf10 is also essential for budding of the prostate [141]. This raises the possibility of an RA-Fgf10 axis for bud outgrowth as has been demonstrated for the lung.

\section{Definitive Endoderm vs. the Extraembryonic Endoderm Lineage}

It has been nearly 40 years since investigators recognized that mouse teratocarcinoma cells could be chemically differentiated into the extraembryonic endoderm (ExEn) lineage [142], recapitulating that which develops in the mouse embryo at E4.5 just before implantation (Figure 3) [143,144]. Chemical induced differentiation has since been reported for human embryonal carcinoma (EC) cells [145] and for human and mouse embryonic stem (ES) cells [146-150]. One of these specific chemicals is RA, which is indispensable for embryonic development [2,151] and depending on the context is considered an inducer, a morphogen and/or a teratogen to developing embryos. In vitro models, including the F9 teratocarcinoma cell line have been instrumental in our understanding of retinoid signaling [152], and it is well known that when F9 cells are treated with RA, they differentiate as primitive extraembryonic endoderm (PrE) [31]. Moreover, RA in combination with agents like dibutyryl cAMP (db-cAMP), parathyroid hormone (PTH) or PTH-related peptide (PTHrP), to increase protein kinase A (PKA) activity, induce PrE cells to differentiate into parietal endoderm (PE) [142,153-156]. Interestingly, whereas RA commits cells to form PrE, in other cases when RA is not used, the commitment is transient when the inducing signal is removed [30,157]. Nevertheless, RA treatment leading to differentiation of the extraembryonic endoderm lineage is accompanied by the concomitant increase in tissue plasminogen activator (tPA) [158] and decrease in the levels of stage-specific embryonic antigen [159], both commonly linked to the loss of pluripotency. Growing F9 cells in suspension and in the presence of RA also allows for the differentiation of visceral endoderm (VE), which is morphologically and biochemically distinct from PE as these cells synthesize alpha-fetoprotein [144,160,161].

In addition to the changes in gene expression noted above, EC and ES cells have shed considerable light on the fact that ExEn differentiation is accompanied by significant changes in gene expression, and this has been reported in several gene-profiling studies [152,162-172], including both positive and negative regulation imposed on the RA receptors themselves [173,174]. Although assembling these changes in gene regulation into a hierarchy or network has until recent been problematic, integrative genomics have nevertheless revealed the diversity of distinct regulatory programs involved in RA signaling during F9 cell differentiation [175]. This diversity is even more complex given the epigenetic regulation that was identified as playing a role in VE differentiation [176]. A recent review has since highlighted the role RA plays in epigenetic mechanisms of stem cell differentiation [177]. Finally, and 
in addition to these RA-induced epi/genomic changes, there is evidence that cell-cell and cell-matrix interactions are also involved in the specification of PE and VE [178], and this is influenced by noncanonical Wnt signaling [179].

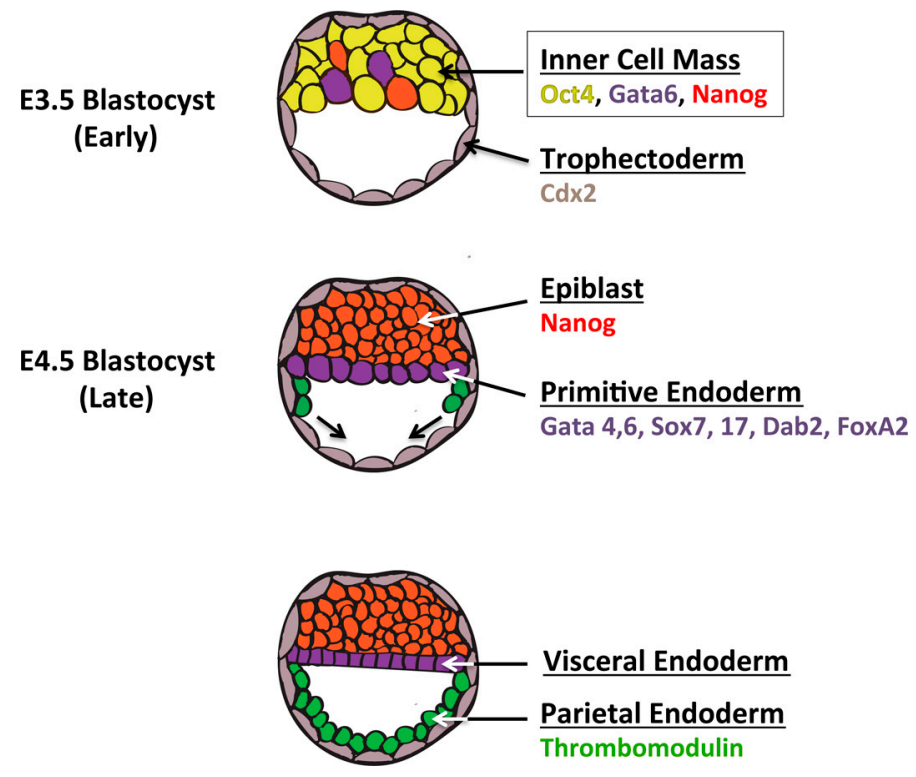

Figure 3. Formation of extraembryonic endoderm in mouse development. Cells of the inner cell mass (yellow), expressing Oct4, Gata6 and Nanog, and those of the trophectoderm (grey), expressing $C d x 2$, are the primary cell populations present prior to implantation of the blastocyst. A second round of segregation leads to cells of the epiblast (red), which continue to express Nanog and will eventually give rise to the three germ layers of the embryo proper, and those committed towards the extraembryonic endoderm lineage that express Gata4 and 6, Sox7 and 17,Dab2 and FoxA2. Soon after, cells of the primitive extraembryonic endoderm that undergo an epithelial-to-mesenchymal transition, migrate on a basement membrane along the trophectoderm and develop as parietal extraembryonic endoderm (green). Primitive endoderm cells still associated with the basement membrane of the epiblast acquire a cuboidal morphology, and develop into visceral extraembryonic endoderm (purple); some of which contributes to definitive endoderm.

Deciphering these regulatory programs involved in ExEn differentiation has revealed that while similarities exist between the differentiation of mouse and human EC cell lines [180], differences even between mammalian species preclude formalizing generalizations; the same is also true for ES cells between different species [181,182]. Nevertheless, the host of profiling studies mentioned above documenting the ability of RA to regulate the expression of a plethora of genes in F9 cells has been complemented by several detailed studies on specific genes including Rex-1 [183], laminin B1 [184], Mct8 [185], Disabled-2 [186,187] and PTH/PTHrP [188], to name a few. In the case of the latter, and as described above, RA exposure followed by subsequent treatment of PTH or PTHrP is sufficient to induce F9 cells to form PE [189-191]. PTHrP bound to its G-protein coupled PTH/PTHrP receptor (GPCR) stimulates adenylyl cyclase to increase cAMP levels [192]. These and other studies have shown that while RA induced differentiation is accompanied by an increase in Ras/ERK activity leading to PrE, this activity must be attenuated by increased PKA signaling in order for cells to develop into 
PE [189,193,194]. Evidence from in vivo expression and localization studies and from work with ES cells support this model [195-198]. PTHrP activation of its GPCR also leads to the up-regulation of an immediate early target gene encoding the transcriptional repressor Snail1 [199], which accumulates in response to the inhibition of Glycogen Synthase Kinase-3 and serves to negatively regulate $C d h 1$, which encodes E-cadherin [200]. This signaling axis has expanded to include other players and it is now generally accepted that extensive crosstalk between disparate signaling pathways are necessary for patterning ExEn. One of these pathways involves heterotrimeric G-protein signaling activated by RA in F9 cells [201,202] and in P19 cells [203-207]. Other gene networks induced by RA include, but are not limited to thyroid hormone signaling involving monocarboxylate transporters [185] and to the positive and negative regulation imparted on the non-canonical and canonical Wnt pathways [30,179,201,208-213]; the latter also linked to Snail1 stabilization.

At the center of all of these signaling pathways involved in the differentiation of the ExEn lineage are transcription factors and transcriptional regulators, some which are regulated directly or indirectly by RA. This is an ever-increasing pool that includes GATA binding proteins 4 and 6 [214,215], the Sry-related HMG-box transcription factor Sox7 and Sox17 [216-220], transcription factor 2, Tcf2 (vHnf-1b) [221], FoxA1 (Hnf-3a) [222], FoxA2 (Hnf-3b) [223], Hnf-4 [224] and Disabled-2 [225,226]. These and many more have been identified and validated by microarray analysis of ExEn isolated from embryos [227]. As with the complexity of the epigenetics introduced earlier, teasing apart the intricacies of this transcriptional regulation is convoluted by the fact that these transcription factors often regulate the expression of each other, as in the case of Sox 7 up-regulating Gata 4 and 6 expression [220], Gata6 activating Gata4 [228], the feed-back and feed-forward loops between Disabled-2, Gata4 and Gata6 [226], Tcf2 (vHnf-1b) and Gata6 linked to Hnf-4al, Hnfla and Hnf3g (FoxA3) expression [221,228], and finally Gata6 inducing FoxA2 [229].

Many of the pathways and participating players noted above that induce naïve cells to form the ExEn lineage are also known to be involved in patterning the definitive endoderm [13,23,230,231]. Towards that end, recent advances with eXtra-embryonic ENdoderm (XEN) cells [232,233], which can be induced from ES cells by RA treatment or by overexpressing Gata6 [29,234,235], and with two other ExEn cell lines, END2 and PYS2 [236], are slowly unraveling the signals that not only pattern extraembryonic and definitive endoderms, but also mesodermal and ectodermal tissues. Epigenetic changes known to regulate the differentiation of ES cells, noted earlier, also contribute to defining the fate of XEN cells, which has a DNA methylation signature that differs from ES, epiblast or trophoblast stem cells [237]. Even within the same XEN cells, the balance and crosstalk between pathways play a critical role in dictating the lineage that will differentiate. This is seen in rat XEN cells that form VE when canonical Wnt signaling is activated, but develop into PE following the activation of the PTHrP pathway [181]. Thus, although much remains to be learned, studying how the ExEn lineage is patterned using in vitro models has merit as it has provided the basis for potential therapeutic applications of differentiating ExEn into definitive embryonic endoderm [182]. Although RA per se may not be necessary in these processes, the importance of retinoid signaling as described above, again in combination with several other signaling pathways, is nevertheless crucial in patterning and shaping definitive endodermal structures [238]. 


\section{Future Directions}

Although we now know that retinoic acid is absolutely required for the development of most endodermal organs, there are several questions that need to be addressed before we fully understand the details of its role in the endodermal development. Given the ability of retinoic acid to signal across cells, understanding the site of action(s) for retinoic acid remains difficult. For example, patterning of the endoderm is in part controlled by the overlying lateral plate mesoderm $[77,84]$ and retinoic acid can act on both tissues [53,123]. Evidence from reporters of retinoic acid signaling suggests that it will be a combination of both. As more sophisticated genetic models are developed, where Aldhla2 or the RA receptors are eliminated in specific tissues or times, the relative contributions of mesoderm and endoderm RA signaling and responses can be addressed. Such models will also be useful in delineating the roles of RA at different time periods during development. For example, it is clear that RA is needed for precisely positioning the lung along the anterior-posterior axis, for lung bud outgrowth, branching morphogenesis and subsequent maturation of the functioning lung. To what degree the later events are due to defects in an early process that requires RA signaling, or are later, independent RA signaling events can be partially worked out with the careful use of inhibitors but the definitive work with conditional knockout animals should be able to tease out different temporal requirements for RA signaling. This information is likely critical for better differentiation protocols used to drive stem cells into specific endodermal cell types. At present, RA is a key ingredient in most protocols used to drive endoderm development [239,240] and the RA is present over multiple differentiation steps. It is possible that more regulated timing of the RA signal is necessary for further optimization of differentiation protocols and better understanding of the normal development may provide rationales for making those changes.

Retinoic acid does not act alone in regulating tissue differentiation and growth but in most cases, our knowledge of the relationship between RA signaling and other pathways remains rudimentary. Interactions between RA signaling and other signaling pathways have been well detailed in the lung [88] and in the development of the extraembryonic endoderm [201,211] but it remains likely that even our understanding of those interactions is limited. It has been suggested that the specificity for RA signaling comes from its role in regulating local signaling networks rather than a gradient of retinoic acid activating different targets at different concentrations [88] and identifying those local networks will be important for a clear understanding of specific roles in individual tissues. Interestingly, one of the best documented interactions is the role of retinoic acid is in regulating Fgflo expression in the lung [88] yet this interaction appears to be also linked with the stomach [131] and some non-endoderm derived tissues [241,242]. This RA-Fgf10 interaction may represent a module for expansion of the tissue rather than specification and is thus used for several organ systems independently.

Our understanding of the transcriptional targets of RA signaling is also limited. The advent of chromatin immunoprecipitation (ChIP) to identify targets has begun $[69,70]$ but in the case of the RA receptors, there are clear difficulties that must be overcome. For most targets, the RA receptors will be present on the promoter regardless of whether that promoter is transcriptionally active or not and thus interpreting the information will require additional epigenetic (ChIP) data at those sites to determine the likely transcriptional status associated with specific RAREs. Another technical issue is obtaining the starting material from small, localized populations of endodermal organ precursors. This represents a 
significant challenge but would be necessary to determine the specificity of the development program within those early organ systems. However, these are technical challenges that future scientists should be able to overcome and the information will provide important new data in our understanding of this fascinating signaling system and its role in endodermal development.

\section{Acknowledgments}

Both T.A.D. and G.M.K. gratefully acknowledge the Natural Sciences and Engineering Council of Canada (NSERC) funding that was used to support this work. G.M.K. would like to dedicate his part of the review to I. Sarafov for her inspiration and continual support. We also thank the anonymous reviewers for useful suggestions, and acknowledge the Children's Health Research Institute for providing support and encouragement.

\section{Author Contributions}

Both T.A.D. and G.M.K. wrote the review with extensive collaboration and discussion.

\section{Conflicts of Interest}

The authors declare no conflict of interest.

\section{References}

1. Duester, G. Retinoic acid synthesis and signaling during early organogenesis. Cell 2008, 134, 921-931.

2. Rhinn, M.; Dolle, P. Retinoic acid signalling during development. Development 2012, 139, 843-858.

3. Fujiwara, S.; Kawamura, K. Acquisition of retinoic acid signaling pathway and innovation of the chordate body plan. Zoolog. Sci. 2003, 20, 809-818.

4. Marletaz, F.; Holland, L.Z.; Laudet, V.; Schubert, M. Retinoic acid signaling and the evolution of chordates. Int. J. Biol. Sci. 2006, 2, 38-47.

5. Canestro, C.; Postlethwait, J.H.; Gonzalez-Duarte, R.; Albalat, R. Is retinoic acid genetic machinery a chordate innovation? Evol. Dev. 2006, 8, 394-406.

6. Simoes-Costa, M.S.; Azambuja, A.P.; Xavier-Neto, J. The search for non-chordate retinoic acid signaling: Lessons from chordates. J. Exp. Zool. B Mol. Dev. Evol. 2008, 310, 54-72.

7. Albalat, R. The retinoic acid machinery in invertebrates: Ancestral elements and vertebrate innovations. Mol. Cell. Endocrinol 2009, 313, 23-35.

8. Canestro, C.; Postlethwait, J.H. Development of a chordate anterior-posterior axis without classical retinoic acid signaling. Dev. Biol. 2007, 305, 522-538.

9. Stafford, D.; Prince, V.E. Retinoic acid signaling is required for a critical early step in zebrafish pancreatic development. Curr. Biol. 2002, 12, 1215-1220.

10. Chen, Y.; Pan, F.C.; Brandes, N.; Afelik, S.; Solter, M.; Pieler, T. Retinoic acid signaling is essential for pancreas development and promotes endocrine at the expense of exocrine cell differentiation in xenopus. Dev. Biol. 2004, 271, 144-160. 
11. Bayha, E.; Jorgensen, M.C.; Serup, P.; Grapin-Botton, A. Retinoic acid signaling organizes endodermal organ specification along the entire antero-posterior axis. PLoS One 2009, 4, e5845.

12. Hashimshony, T.; Feder, M.; Levin, M.; Hall, B.K.; Yanai, I. Spatiotemporal transcriptomics reveals the evolutionary history of the endoderm germ layer. Nature 2015, 519, 219-222.

13. Zorn, A.M.; Wells, J.M. Vertebrate endoderm development and organ formation. Annu. Rev. Cell. Dev. Biol. 2009, 25, 221-251.

14. Warga, R.M.; Nusslein-Volhard, C. Origin and development of the zebrafish endoderm. Development 1999, 126, 827-838.

15. Rodaway, A.; Takeda, H.; Koshida, S.; Broadbent, J.; Price, B.; Smith, J.C.; Patient, R.; Holder, N. Induction of the mesendoderm in the zebrafish germ ring by yolk cell-derived tgf-beta family signals and discrimination of mesoderm and endoderm by fgf. Development 1999, 126, 3067-3078.

16. Lemaire, P.; Darras, S.; Caillol, D.; Kodjabachian, L. A role for the vegetally expressed xenopus gene mix.1 in endoderm formation and in the restriction of mesoderm to the marginal zone. Development 1998, 125, 2371-2380.

17. Maduro, M.F.; Meneghini, M.D.; Bowerman, B.; Broitman-Maduro, G.; Rothman, J.H. Restriction of mesendoderm to a single blastomere by the combined action of skn-1 and a gsk-3beta homolog is mediated by med-1 and -2 in c. Elegans. Mol. Cell. 2001, 7, 475-485.

18. Technau, U.; Scholz, C.B. Origin and evolution of endoderm and mesoderm. Int. J. Dev. Biol. 2003, 47, 531-539.

19. Shen, M.M. Nodal signaling: Developmental roles and regulation. Development 2007, 134, 1023-1034.

20. Chen, Y.; Schier, A.F. The zebrafish nodal signal squint functions as a morphogen. Nature 2001, 411,607-610.

21. Kruithof-de Julio, M.; Alvarez, M.J.; Galli, A.; Chu, J.; Price, S.M.; Califano, A.; Shen, M.M. Regulation of extra-embryonic endoderm stem cell differentiation by nodal and cripto signaling. Development 2011, 138, 3885-3895.

22. Liu, W.; Brown, K.; Legros, S.; Foley, A.C. Nodal mutant extraembryonic endoderm (xen) stem cells upregulate markers for the anterior visceral endoderm and impact the timing of cardiac differentiation in mouse embryoid bodies. Biol Open 2012, 1, 208-219.

23. Zorn, A.M.; Wells, J.M. Molecular basis of vertebrate endoderm development. Int Rev. Cytol 2007, 259, 49-111.

24. Chiu, W.T.; Charney Le, R.; Blitz, I.L.; Fish, M.B.; Li, Y.; Biesinger, J.; Xie, X.; Cho, K.W. Genome-wide view of tgfbeta/foxh1 regulation of the early mesendoderm program. Development 2014, 141, 4537-4547.

25. Uehara, M.; Yashiro, K.; Takaoka, K.; Yamamoto, M.; Hamada, H. Removal of maternal retinoic acid by embryonic cyp26 is required for correct nodal expression during early embryonic patterning. Genes Dev. 2009, 23, 1689-1698.

26. Liu, P.; Wakamiya, M.; Shea, M.J.; Albrecht, U.; Behringer, R.R.; Bradley, A. Requirement for wnt3 in vertebrate axis formation. Nat. Genet. 1999, 22, 361-365.

27. Brennan, J.; Lu, C.C.; Norris, D.P.; Rodriguez, T.A.; Beddington, R.S.; Robertson, E.J. Nodal signalling in the epiblast patterns the early mouse embryo. Nature 2001, 411, 965-969. 
28. McCracken, K.W.; Cata, E.M.; Crawford, C.M.; Sinagoga, K.L.; Schumacher, M.; Rockich, B.E.; Tsai, Y.H.; Mayhew, C.N.; Spence, J.R.; Zavros, Y.; et al. Modelling human development and disease in pluripotent stem-cell-derived gastric organoids. Nature 2014, 516, 400-404.

29. Niakan, K.K.; Schrode, N.; Cho, L.T.; Hadjantonakis, A.K. Derivation of extraembryonic endoderm stem (xen) cells from mouse embryos and embryonic stem cells. Nat. Protoc. 2013, 8 , 1028-1041.

30. Krawetz, R.; Kelly, G.M. Wnt6 induces the specification and epithelialization of F9 embryonal carcinoma cells to primitive endoderm. Cell. Signal. 2008, 20, 506-517.

31. Grover, A.; Adamson, E.D. Evidence for the existence of an early common biochemical pathway in the differentiation of $\mathrm{f} 9$ cells into visceral or parietal endoderm: Modulation by cyclic amp. Dev. Biol. 1986, 114, 492-503.

32. Mark, M.; Ghyselinck, N.B.; Chambon, P. Function of retinoid nuclear receptors: Lessons from genetic and pharmacological dissections of the retinoic acid signaling pathway during mouse embryogenesis. Annu. Rev. Pharmacol. Toxicol. 2006, 46, 451-480.

33. Mark, M.; Ghyselinck, N.B.; Chambon, P. Function of retinoic acid receptors during embryonic development. Nucl. Recept. Signal. 2009, 7, e002.

34. Farjo, K.M.; Moiseyev, G.; Nikolaeva, O.; Sandell, L.L.; Trainor, P.A.; Ma, J.X. Rdh10 is the primary enzyme responsible for the first step of embryonic vitamin a metabolism and retinoic acid synthesis. Dev. Biol. 2011, 357, 347-355.

35. Rhinn, M.; Schuhbaur, B.; Niederreither, K.; Dolle, P. Involvement of retinol dehydrogenase 10 in embryonic patterning and rescue of its loss of function by maternal retinaldehyde treatment. Proc. Natl. Acad. Sci. USA 2011, 108, 16687-16692.

36. Sandell, L.L.; Lynn, M.L.; Inman, K.E.; McDowell, W.; Trainor, P.A. Rdh10 oxidation of vitamin a is a critical control step in synthesis of retinoic acid during mouse embryogenesis. PLoS One 2012, 7, e30698.

37. Strate, I.; Min, T.H.; Iliev, D.; Pera, E.M. Retinol dehydrogenase 10 is a feedback regulator of retinoic acid signalling during axis formation and patterning of the central nervous system. Development 2009, 136, 461-472.

38. Feng, L.; Hernandez, R.E.; Waxman, J.S.; Yelon, D.; Moens, C.B. Dhrs3a regulates retinoic acid biosynthesis through a feedback inhibition mechanism. Dev. Biol. 2010, 338, 1-14.

39. Kumar, S.; Sandell, L.L.; Trainor, P.A.; Koentgen, F.; Duester, G. Alcohol and aldehyde dehydrogenases: Retinoid metabolic effects in mouse knockout models. Biochim. Biophys. Acta 2012, 1821, 198-205.

40. Lee, L.M.; Leung, C.Y.; Tang, W.W.; Choi, H.L.; Leung, Y.C.; McCaffery, P.J.; Wang, C.C.; Woolf, A.S.; Shum, A.S. A paradoxical teratogenic mechanism for retinoic acid. Proc. Natl. Acad. Sci. USA 2012, 109, 13668-13673.

41. Niederreither, K.; Fraulob, V.; Garnier, J.M.; Chambon, P.; Dolle, P. Differential expression of retinoic acid-synthesizing (raldh) enzymes during fetal development and organ differentiation in the mouse. Mech. Dev. 2002, 110, 165-171.

42. Niederreither, K.; Subbarayan, V.; Dolle, P.; Chambon, P. Embryonic retinoic acid synthesis is essential for early mouse post-implantation development. Nat. Genet. 1999, 21, 444-448. 
43. Niederreither, K.; Vermot, J.; Messaddeq, N.; Schuhbaur, B.; Chambon, P.; Dolle, P. Embryonic retinoic acid synthesis is essential for heart morphogenesis in the mouse. Development 2001, 128, 1019-1031.

44. Niederreither, K.; Vermot, J.; Schuhbaur, B.; Chambon, P.; Dolle, P. Embryonic retinoic acid synthesis is required for forelimb growth and anteroposterior patterning in the mouse. Development 2002, 129, 3563-3574.

45. Niederreither, K.; Dolle, P. Retinoic acid in development: Towards an integrated view. Nat. Rev. Genet. 2008, 9, 541-553.

46. Fan, X.; Molotkov, A.; Manabe, S.; Donmoyer, C.M.; Deltour, L.; Foglio, M.H.; Cuenca, A.E.; Blaner, W.S.; Lipton, S.A.; Duester, G. Targeted disruption of aldh1a1 (raldh1) provides evidence for a complex mechanism of retinoic acid synthesis in the developing retina. Mol. Cell. Biol. 2003, 23, 4637-4648.

47. Dupe, V.; Matt, N.; Garnier, J.M.; Chambon, P.; Mark, M.; Ghyselinck, N.B. A newborn lethal defect due to inactivation of retinaldehyde dehydrogenase type 3 is prevented by maternal retinoic acid treatment. Proc. Natl. Acad. Sci. USA 2003, 100, 14036-14041.

48. Chatzi, C.; Brade, T.; Duester, G. Retinoic acid functions as a key gabaergic differentiation signal in the basal ganglia. PLoS Biol. 2011, 9, e1000609.

49. Chambers, D.; Wilson, L.; Maden, M.; Lumsden, A. Raldh-independent generation of retinoic acid during vertebrate embryogenesis by cyp1b1. Development 2007, 134, 1369-1383.

50. Lampert, J.M.; Holzschuh, J.; Hessel, S.; Driever, W.; Vogt, K.; von Lintig, J. Provitamin a conversion to retinal via the beta,beta-carotene-15,15'-oxygenase (bcox) is essential for pattern formation and differentiation during zebrafish embryogenesis. Development 2003, 130, 2173-2186.

51. Kim, Y.K.; Wassef, L.; Chung, S.; Jiang, H.; Wyss, A.; Blaner, W.S.; Quadro, L. Beta-carotene and its cleavage enzyme beta-carotene-15,15'-oxygenase (cmoi) affect retinoid metabolism in developing tissues. FASEB J. 2011, 25, 1641-1652.

52. Hessel, S.; Eichinger, A.; Isken, A.; Amengual, J.; Hunzelmann, S.; Hoeller, U.; Elste, V.; Hunziker, W.; Goralczyk, R.; Oberhauser, V.; et al. Cmol deficiency abolishes vitamin a production from beta-carotene and alters lipid metabolism in mice. J. Biol. Chem. 2007, 282, 33553-33561.

53. Molotkov, A.; Molotkova, N.; Duester, G. Retinoic acid generated by raldh2 in mesoderm is required for mouse dorsal endodermal pancreas development. Dev. Dyn. 2005, 232, 950-957.

54. Pennimpede, T.; Cameron, D.A.; MacLean, G.A.; Li, H.; Abu-Abed, S.; Petkovich, M. The role of cyp26 enzymes in defining appropriate retinoic acid exposure during embryogenesis. Birth Defects Res. A Clin Mol. Teratol. 2010, 88, 883-894.

55. Ross, A.C.; Zolfaghari, R. Cytochrome p450s in the regulation of cellular retinoic acid metabolism. Annu. Rev. Nutr. 2011, 31, 65-87.

56. Sakai, Y.; Meno, C.; Fujii, H.; Nishino, J.; Shiratori, H.; Saijoh, Y.; Rossant, J.; Hamada, H. The retinoic acid-inactivating enzyme cyp26 is essential for establishing an uneven distribution of retinoic acid along the anterio-posterior axis within the mouse embryo. Genes Dev. 2001, 15, 213-225. 
57. Abu-Abed, S.; Dolle, P.; Metzger, D.; Beckett, B.; Chambon, P.; Petkovich, M. The retinoic acid-metabolizing enzyme, cyp26a1, is essential for normal hindbrain patterning, vertebral identity, and development of posterior structures. Genes Dev. 2001, 15, 226-240.

58. Hernandez, R.E.; Putzke, A.P.; Myers, J.P.; Margaretha, L.; Moens, C.B. Cyp26 enzymes generate the retinoic acid response pattern necessary for hindbrain development. Development 2007, 134, 177-187.

59. Tibbles, L.; Wiley, M.J. A comparative study of the effects of retinoic acid given during the critical period for inducing spina bifida in mice and hamsters. Teratology 1988, 37, 113-125.

60. Thaller, C.; Eichele, G. Identification and spatial distribution of retinoids in the developing chick limb bud. Nature 1987, 327, 625-628.

61. Cai, A.Q.; Radtke, K.; Linville, A.; Lander, A.D.; Nie, Q.; Schilling, T.F. Cellular retinoic acid-binding proteins are essential for hindbrain patterning and signal robustness in zebrafish. Development 2012, 139, 2150-2155.

62. Lampron, C.; Rochette-Egly, C.; Gorry, P.; Dolle, P.; Mark, M.; Lufkin, T.; LeMeur, M.; Chambon, $\mathrm{P}$. Mice deficient in cellular retinoic acid binding protein ii (crabpii) or in both crabpi and crabpii are essentially normal. Development 1995, 121, 539-548.

63. Ghyselinck, N.B.; Bavik, C.; Sapin, V.; Mark, M.; Bonnier, D.; Hindelang, C.; Dierich, A.; Nilsson, C.B.; Hakansson, H.; Sauvant, P.; et al. Cellular retinol-binding protein i is essential for vitamin a homeostasis. EMBO J. 1999, 18, 4903-4914.

64. Berry, D.C.; Jacobs, H.; Marwarha, G.; Gely-Pernot, A.; O’Byrne, S.M.; DeSantis, D.; Klopfenstein, M.; Feret, B.; Dennefeld, C.; Blaner, W.S.; et al. The stra6 receptor is essential for retinol-binding protein-induced insulin resistance but not for maintaining vitamin a homeostasis in tissues other than the eye. J. Biol. Chem. 2013, 288, 24528-24539.

65. Ruiz, A.; Mark, M.; Jacobs, H.; Klopfenstein, M.; Hu, J.; Lloyd, M.; Habib, S.; Tosha, C.; Radu, R.A.; Ghyselinck, N.B.; et al. Retinoid content, visual responses, and ocular morphology are compromised in the retinas of mice lacking the retinol-binding protein receptor, stra6. Invest. Ophthalmol. Vis. Sci. 2012, 53, 3027-3039.

66. Ng, W.Y.; Pasutto, F.; Bardakjian, T.M.; Wilson, M.J.; Watson, G.; Schneider, A.; Mackey, D.A.; Grigg, J.R.; Zenker, M.; Jamieson, R.V. A puzzle over several decades: Eye anomalies with fras1 and stra6 mutations in the same family. Clin. Genet. 2013, 83, 162-168.

67. Pasutto, F.; Sticht, H.; Hammersen, G.; Gillessen-Kaesbach, G.; Fitzpatrick, D.R.; Nurnberg, G.; Brasch, F.; Schirmer-Zimmermann, H.; Tolmie, J.L.; Chitayat, D.; et al. Mutations in stra6 cause a broad spectrum of malformations including anophthalmia, congenital heart defects, diaphragmatic hernia, alveolar capillary dysplasia, lung hypoplasia, and mental retardation. Am. J. Hum. Genet. 2007, 80, 550-560.

68. Al Tanoury, Z.; Piskunov, A.; Rochette-Egly, C. Vitamin a and retinoid signaling: Genomic and nongenomic effects. J. Lipid Res. 2013, 54, 1761-1775.

69. Moutier, E.; Ye, T.; Choukrallah, M.A.; Urban, S.; Osz, J.; Chatagnon, A.; Delacroix, L.; Langer, D.; Rochel, N.; Moras, D.; et al. Retinoic acid receptors recognize the mouse genome through binding elements with diverse spacing and topology. J. Biol. Chem. 2012, 287, 26328-26341. 
70. Mahony, S.; Mazzoni, E.O.; McCuine, S.; Young, R.A.; Wichterle, H.; Gifford, D.K. Ligand-dependent dynamics of retinoic acid receptor binding during early neurogenesis. Genome Biol. 2011, 12, R2.

71. Al Tanoury, Z.; Gaouar, S.; Piskunov, A.; Ye, T.; Urban, S.; Jost, B.; Keime, C.; Davidson, I.; Dierich, A.; Rochette-Egly, C. Phosphorylation of the retinoic acid receptor rargamma2 is crucial for the neuronal differentiation of mouse embryonic stem cells. J. Cell Sci. 2014, 127, 2095-2105.

72. Al Tanoury, Z.; Piskunov, A.; Andriamoratsiresy, D.; Gaouar, S.; Lutzing, R.; Ye, T.; Jost, B.; Keime, C.; Rochette-Egly, C. Genes involved in cell adhesion and signaling: A new repertoire of retinoic acid receptor target genes in mouse embryonic fibroblasts. J. Cell Sci. 2014, 127, $521-533$.

73. Delacroix, L.; Moutier, E.; Altobelli, G.; Legras, S.; Poch, O.; Choukrallah, M.A.; Bertin, I.; Jost, B.; Davidson, I. Cell-specific interaction of retinoic acid receptors with target genes in mouse embryonic fibroblasts and embryonic stem cells. Mol. Cell. Biol. 2010, 30, 231-244.

74. Rosenfeld, M.G.; Lunyak, V.V.; Glass, C.K. Sensors and signals: A coactivator/corepressor/ epigenetic code for integrating signal-dependent programs of transcriptional response. Genes Dev. 2006, 20, 1405-1428.

75. Hua, S.; Kittler, R.; White, K.P. Genomic antagonism between retinoic acid and estrogen signaling in breast cancer. Cell 2009, 137, 1259-1271.

76. Kashyap, V.; Gudas, L.J. Epigenetic regulatory mechanisms distinguish retinoic acid-mediated transcriptional responses in stem cells and fibroblasts. J. Biol. Chem. 2010, 285, 14534-14548.

77. Kumar, M.; Jordan, N.; Melton, D.; Grapin-Botton, A. Signals from lateral plate mesoderm instruct endoderm toward a pancreatic fate. Dev. Biol. 2003, 259, 109-122.

78. Chen, Y.; Pollet, N.; Niehrs, C.; Pieler, T. Increased xraldh2 activity has a posteriorizing effect on the central nervous system of xenopus embryos. Mech. Dev. 2001, 101, 91-103.

79. Lynch, J.; McEwan, J.; Beck, C.W. Analysis of the expression of retinoic acid metabolising genes during xenopus laevis organogenesis. Gene Expr. Patterns 2011, 11, 112-117.

80. Wang, J.H.; Deimling, S.J.; D’Alessandro, N.E.; Zhao, L.; Possmayer, F.; Drysdale, T.A. Retinoic acid is a key regulatory switch determining the difference between lung and thyroid fates in xenopus laevis. BMC Dev. Biol. 2011, 11, 75.

81. Pera, E.M.; Acosta, H.; Gouignard, N.; Climent, M.; Arregi, I. Active signals, gradient formation and regional specificity in neural induction. Exp. Cell Res. 2014, 321, 25-31.

82. Ribes, V.; Le Roux, I.; Rhinn, M.; Schuhbaur, B.; Dolle, P. Early mouse caudal development relies on crosstalk between retinoic acid, shh and fgf signalling pathways. Development 2009, 136, 665-676.

83. Aulehla, A.; Pourquie, O. Signaling gradients during paraxial mesoderm development. Cold Spring Harb. Perspect. Biol. 2010, 2, a000869.

84. Horb, M.E.; Slack, J.M. Endoderm specification and differentiation in xenopus embryos. Dev. Biol. 2001, 236, 330-343.

85. Deimling, S.J.; Drysdale, T.A. Retinoic acid regulates anterior-posterior patterning within the lateral plate mesoderm of xenopus. Mech. Dev. 2009, 126, 913-923. 
86. Deimling, S.J.; Drysdale, T.A. Fgf is required to regulate anterior-posterior patterning in the xenopus lateral plate mesoderm. Mech. Dev. 2011, 128, 327-341.

87. Tseng, H.T.; Shah, R.; Jamrich, M. Function and regulation of foxf1 during xenopus gut development. Development 2004, 131, 3637-3647.

88. Chen, F.; Cao, Y.; Qian, J.; Shao, F.; Niederreither, K.; Cardoso, W.V. A retinoic acid-dependent network in the foregut controls formation of the mouse lung primordium. J. Clin. Invest. 2010, 120, 2040-2048.

89. Wang, Z.; Dolle, P.; Cardoso, W.V.; Niederreither, K. Retinoic acid regulates morphogenesis and patterning of posterior foregut derivatives. Dev. Biol. 2006, 297, 433-445.

90. Mollard, R.; Ghyselinck, N.B.; Wendling, O.; Chambon, P.; Mark, M. Stage-dependent responses of the developing lung to retinoic acid signaling. Int. J. Dev. Biol. 2000, 44, 457-462.

91. Mendelsohn, C.; Lohnes, D.; Decimo, D.; Lufkin, T.; LeMeur, M.; Chambon, P.; Mark, M. Function of the retinoic acid receptors (rars) during development (ii). Multiple abnormalities at various stages of organogenesis in rar double mutants. Development 1994, 120, 2749-2771.

92. Graham, A.; Smith, A. Patterning the pharyngeal arches. BioEssays 2001, 23, 54-61.

93. Mark, M.; Ghyselinck, N.B.; Chambon, P. Retinoic acid signalling in the development of branchial arches. Curr. Opin. Genet. Dev. 2004, 14, 591-598.

94. Niederreither, K.; Vermot, J.; Le Roux, I.; Schuhbaur, B.; Chambon, P.; Dolle, P. The regional pattern of retinoic acid synthesis by raldh2 is essential for the development of posterior pharyngeal arches and the enteric nervous system. Development 2003, 130, 2525-2534.

95. Kopinke, D.; Sasine, J.; Swift, J.; Stephens, W.Z.; Piotrowski, T. Retinoic acid is required for endodermal pouch morphogenesis and not for pharyngeal endoderm specification. Dev. Dyn. 2006, 235, 2695-2709.

96. Maden, M.; Gale, E.; Kostetskii, I.; Zile, M. Vitamin a-deficient quail embryos have half a hindbrain and other neural defects. Curr. Biol. 1996, 6, 417-426.

97. Dupe, V.; Ghyselinck, N.B.; Wendling, O.; Chambon, P.; Mark, M. Key roles of retinoic acid receptors alpha and beta in the patterning of the caudal hindbrain, pharyngeal arches and otocyst in the mouse. Development 1999, 126, 5051-5059.

98. Matt, N.; Ghyselinck, N.B.; Wendling, O.; Chambon, P.; Mark, M. Retinoic acid-induced developmental defects are mediated by rarbeta/rxr heterodimers in the pharyngeal endoderm. Development 2003, 130, 2083-2093.

99. Wendling, O.; Dennefeld, C.; Chambon, P.; Mark, M. Retinoid signaling is essential for patterning the endoderm of the third and fourth pharyngeal arches. Development 2000, 127, $1553-1562$.

100. Graham, A.; Okabe, M.; Quinlan, R. The role of the endoderm in the development and evolution of the pharyngeal arches. J. Anat. 2005, 207, 479-487.

101. Mulder, G.B.; Manley, N.; Maggio-Price, L. Retinoic acid-induced thymic abnormalities in the mouse are associated with altered pharyngeal morphology, thymocyte maturation defects, and altered expression of hoxa3 and pax1. Teratology 1998, 58, 263-275.

102. Begemann, G.; Schilling, T.F.; Rauch, G.J.; Geisler, R.; Ingham, P.W. The zebrafish neckless mutation reveals a requirement for raldh2 in mesodermal signals that pattern the hindbrain. Development 2001, 128, 3081-3094. 
103. Trainor, P.A.; Krumlauf, R. Hox genes, neural crest cells and branchial arch patterning. Curr. Opin. Cell Biol. 2001, 13, 698-705.

104. Nolte, C.; Jinks, T.; Wang, X.; Martinez Pastor, M.T.; Krumlauf, R. Shadow enhancers flanking the hoxb cluster direct dynamic hox expression in early heart and endoderm development. Dev. Biol. 2013, 383, 158-173.

105. Ryckebusch, L.; Bertrand, N.; Mesbah, K.; Bajolle, F.; Niederreither, K.; Kelly, R.G.; Zaffran, S. Decreased levels of embryonic retinoic acid synthesis accelerate recovery from arterial growth delay in a mouse model of digeorge syndrome. Circ. Res. 2010, 106, 686-694.

106. Schubert, M.; Yu, J.K.; Holland, N.D.; Escriva, H.; Laudet, V.; Holland, L.Z. Retinoic acid signaling acts via hox 1 to establish the posterior limit of the pharynx in the chordate amphioxus. Development 2005, 132, 61-73.

107. Dickman, E.D.; Thaller, C.; Smith, S.M. Temporally-regulated retinoic acid depletion produces specific neural crest, ocular and nervous system defects. Development 1997, 124, 3111-3121.

108. Desai, T.J.; Chen, F.; Lu, J.; Qian, J.; Niederreither, K.; Dolle, P.; Chambon, P.; Cardoso, W.V. Distinct roles for retinoic acid receptors alpha and beta in early lung morphogenesis. Dev. Biol 2006, 291, 12-24.

109. Chen, F.; Desai, T.J.; Qian, J.; Niederreither, K.; Lu, J.; Cardoso, W.V. Inhibition of tgf beta signaling by endogenous retinoic acid is essential for primary lung bud induction. Development 2007, 134, 2969-2979.

110. Desai, T.J.; Malpel, S.; Flentke, G.R.; Smith, S.M.; Cardoso, W.V. Retinoic acid selectively regulates fgf10 expression and maintains cell identity in the prospective lung field of the developing foregut. Dev. Biol 2004, 273, 402-415.

111. Malpel, S.; Mendelsohn, C.; Cardoso, W.V. Regulation of retinoic acid signaling during lung morphogenesis. Development 2000, 127, 3057-3067.

112. Wilson, J.G.; Roth, C.B.; Warkany, J. An analysis of the syndrome of malformations induced by maternal vitamin a deficiency. Effects of restoration of vitamin a at various times during gestation. Am. J. Anat. 1953, 92, 189-217.

113. Bellusci, S.; Grindley, J.; Emoto, H.; Itoh, N.; Hogan, B.L. Fibroblast growth factor 10 (fgf10) and branching morphogenesis in the embryonic mouse lung. Development 1997, 124, 4867-4878.

114. Vermot, J.; Pourquie, O. Retinoic acid coordinates somitogenesis and left-right patterning in vertebrate embryos. Nature 2005, 435, 215-220.

115. Vilhais-Neto, G.C.; Maruhashi, M.; Smith, K.T.; Vasseur-Cognet, M.; Peterson, A.S.; Workman, J.L.; Pourquie, O. Rere controls retinoic acid signalling and somite bilateral symmetry. Nature 2010, 463, 953-957.

116. Garnaas, M.K.; Cutting, C.C.; Meyers, A.; Kelsey, P.B., Jr.; Harris, J.M.; North, T.E.; Goessling, W. Rargb regulates organ laterality in a zebrafish model of right atrial isomerism. Dev. Biol. 2012, 372, 178-189.

117. Lipscomb, K.; Schmitt, C.; Sablyak, A.; Yoder, J.A.; Nascone-Yoder, N. Role for retinoid signaling in left-right asymmetric digestive organ morphogenesis. Dev. Dyn. 2006, 235, 2266-2275.

118. Gavrilova, R.; Babovic, N.; Lteif, A.; Eidem, B.; Kirmani, S.; Olson, T.; Babovic-Vuksanovic, D. Vitamin a deficiency in an infant with pagod syndrome. Am. J. Med. Genet. A 2009, 149A, 2241-2247. 
119. Golzio, C.; Martinovic-Bouriel, J.; Thomas, S.; Mougou-Zrelli, S.; Grattagliano-Bessieres, B.; Bonniere, M.; Delahaye, S.; Munnich, A.; Encha-Razavi, F.; Lyonnet, S.; et al. Matthew-wood syndrome is caused by truncating mutations in the retinol-binding protein receptor gene stra6. Am. J. Hum. Genet. 2007, 80, 1179-1187.

120. Chen, F.; Marquez, H.; Kim, Y.K.; Qian, J.; Shao, F.; Fine, A.; Cruikshank, W.W.; Quadro, L.; Cardoso, W.V. Prenatal retinoid deficiency leads to airway hyperresponsiveness in adult mice. $J$. Clin. Invest. 2014, 124, 801-811.

121. Martin, M.; Gallego-Llamas, J.; Ribes, V.; Kedinger, M.; Niederreither, K.; Chambon, P.; Dolle, P.; Gradwohl, G. Dorsal pancreas agenesis in retinoic acid-deficient raldh2 mutant mice. Dev. Biol. 2005, 284, 399-411.

122. Stafford, D.; White, R.J.; Kinkel, M.D.; Linville, A.; Schilling, T.F.; Prince, V.E. Retinoids signal directly to zebrafish endoderm to specify insulin-expressing beta-cells. Development 2006, 133, 949-956.

123. Ostrom, M.; Loffler, K.A.; Edfalk, S.; Selander, L.; Dahl, U.; Ricordi, C.; Jeon, J.; Correa-Medina, M.; Diez, J.; Edlund, H. Retinoic acid promotes the generation of pancreatic endocrine progenitor cells and their further differentiation into beta-cells. PLoS One 2008, 3, e2841.

124. Kinkel, M.D.; Sefton, E.M.; Kikuchi, Y.; Mizoguchi, T.; Ward, A.B.; Prince, V.E. Cyp26 enzymes function in endoderm to regulate pancreatic field size. Proc. Natl. Acad. Sci. USA 2009, 106, 7864-7869.

125. Stafford, D.; Hornbruch, A.; Mueller, P.R.; Prince, V.E. A conserved role for retinoid signaling in vertebrate pancreas development. Dev. Genes Evol. 2004, 214, 432-441.

126. Alexa, K.; Choe, S.K.; Hirsch, N.; Etheridge, L.; Laver, E.; Sagerstrom, C.G. Maternal and zygotic aldh1a2 activity is required for pancreas development in zebrafish. PLoS One 2009, 4, e8261.

127. Trasino, S.E.; Benoit, Y.D.; Gudas, L.J. Vitamin a deficiency causes hyperglycemia and loss of pancreatic beta-cell mass. J. Biol. Chem. 2015, 290, 1456-1473.

128. Shiota, G.; Kanki, K. Retinoids and their target genes in liver functions and diseases. $J$. Gastroenterol. Hepatol. 2013, 28 (Suppl. S1), 33-37.

129. Li, Z.; Korzh, V.; Gong, Z. Localized rbp4 expression in the yolk syncytial layer plays a role in yolk cell extension and early liver development. BMC Dev. Biol. 2007, 7, 117.

130. Grapin-Botton, A. Antero-posterior patterning of the vertebrate digestive tract: 40 years after Nicole le Douarin's PhD thesis. Inte. J. Dev. Biol. 2005, 49, 335-347.

131. Spencer-Dene, B.; Sala, F.G.; Bellusci, S.; Gschmeissner, S.; Stamp, G.; Dickson, C. Stomach development is dependent on fibroblast growth factor 10/fibroblast growth factor receptor 2b-mediated signaling. Gastroenterology 2006, 130, 1233-1244.

132. Zeynali, B.; Dixon, K.E. Effects of retinoic acid on the endoderm in xenopus embryos. Dev. Genes Evol. 1998, 208, 318-326.

133. Pitera, J.E.; Smith, V.V.; Woolf, A.S.; Milla, P.J. Embryonic gut anomalies in a mouse model of retinoic acid-induced caudal regression syndrome: Delayed gut looping, rudimentary cecum, and anorectal anomalies. Am. J. Pathol. 2001, 159, 2321-2329. 
134. Bloom, S.; Ledon-Rettig, C.; Infante, C.; Everly, A.; Hanken, J.; Nascone-Yoder, N. Developmental origins of a novel gut morphology in frogs. Evol. Dev. 2013, 15, 213-223.

135. Huang, D.; Chen, S.W.; Langston, A.W.; Gudas, L.J. A conserved retinoic acid responsive element in the murine hoxb-1 gene is required for expression in the developing gut. Development 1998, 125, 3235-3246.

136. Wright-Jin, E.C.; Grider, J.R.; Duester, G.; Heuckeroth, R.O. Retinaldehyde dehydrogenase enzymes regulate colon enteric nervous system structure and function. Dev. Biol. 2013, 381, 28-37.

137. Sato, Y.; Heuckeroth, R.O. Retinoic acid regulates murine enteric nervous system precursor proliferation, enhances neuronal precursor differentiation, and reduces neurite growth in vitro. Dev. Biol. 2008, 320, 185-198.

138. Nadauld, L.D.; Shelton, D.N.; Chidester, S.; Yost, H.J.; Jones, D.A. The zebrafish retinol dehydrogenase, rdh11, is essential for intestinal development and is regulated by the tumor suppressor adenomatous polyposis coli. J. Biol. Chem. 2005, 280, 30490-30495.

139. Nadauld, L.D.; Sandoval, I.T.; Chidester, S.; Yost, H.J.; Jones, D.A. Adenomatous polyposis coli control of retinoic acid biosynthesis is critical for zebrafish intestinal development and differentiation. J. Biol. Chem. 2004, 279, 51581-51589.

140. Vezina, C.M.; Allgeier, S.H.; Fritz, W.A.; Moore, R.W.; Strerath, M.; Bushman, W.; Peterson, R.E. Retinoic acid induces prostatic bud formation. Dev. Dyn. 2008, 237, 1321-1333.

141. Thomson, A.A.; Cunha, G.R. Prostatic growth and development are regulated by fgf10. Development 1999, 126, 3693-3701.

142. Strickland, S.; Mahdavi, V. The induction of differentiation in teratocarcinoma stem cells by retinoic acid. Cell 1978, 15, 393-403.

143. Gachelin, G. Experimental teratocarcinoma in mice: A model system for the study of the relationship between cellular surface antigens and embryonic differentiation. Bull. Cancer 1976, 63, 95-110 (In French).

144. Hogan, B.L.; Taylor, A.; Adamson, E. Cell interactions modulate embryonal carcinoma cell differentiation into parietal or visceral endoderm. Nature 1981, 291, 235-237.

145. Roach, S.; Schmid, W.; Pera, M.F. Hepatocytic transcription factor expression in human embryonal carcinoma and yolk sac carcinoma cell lines: Expression of hnf-3 alpha in models of early endodermal cell differentiation. Exp. Cell Res. 1994, 215, 189-198.

146. Capo-Chichi, C.D.; Rula, M.E.; Smedberg, J.L.; Vanderveer, L.; Parmacek, M.S.; Morrisey, E.E.; Godwin, A.K.; Xu, X.X. Perception of differentiation cues by gata factors in primitive endoderm lineage determination of mouse embryonic stem cells. Dev. Biol. 2005, 286, 574-586.

147. Bielinska, M.; Wilson, D.B. Induction of yolk sac endoderm in gata-4-deficient embryoid bodies by retinoic acid. Mech. Dev. 1997, 65, 43-54.

148. Feng, X.; Zhang, J.; Smuga-Otto, K.; Tian, S.; Yu, J.; Stewart, R.; Thomson, J.A. Protein kinase c mediated extraembryonic endoderm differentiation of human embryonic stem cells. Stem Cells 2012, 30, 461-470.

149. Papalopulu, N.; Lovell-Badge, R.; Krumlauf, R. The expression of murine hox-2 genes is dependent on the differentiation pathway and displays a collinear sensitivity to retinoic acid in $\mathrm{f} 9$ cells and xenopus embryos. Nucleic Acids Res. 1991, 19, 5497-5506. 
150. Mummery, C.L.; Feyen, A.; Freund, E.; Shen, S. Characteristics of embryonic stem cell differentiation: A comparison with two embryonal carcinoma cell lines. Cell Differ. Dev. 1990, 30, 195-206.

151. Bielinska, M.; Narita, N.; Wilson, D.B. Distinct roles for visceral endoderm during embryonic mouse development. Int. J. Dev. Biol. 1999, 43, 183-205.

152. Rochette-Egly, C.; Chambon, P. F9 embryocarcinoma cells: A cell autonomous model to study the functional selectivity of rars and rxrs in retinoid signaling. Histol. Histopathol. 2001, 16, 909-922.

153. Evain, D.; Binet, E.; Anderson, W.B. Alterations in calcitonin and parathyroid hormone responsiveness of adenylate cyclase in $\mathrm{f} 9$ embryonal carcinoma cells treated with retinoic acid and dibutyryl cyclic amp. J. Cell. Phys. 1981, 109, 453-459.

154. Strickland, S.; Smith, K.K.; Marotti, K.R. Hormonal induction of differentiation in teratocarcinoma stem cells: Generation of parietal endoderm by retinoic acid and dibutyryl camp. Cell 1980, 21, 347-355.

155. Evain-Brion, D.; Binet, E.; Donnadieu, M.; Laurent, P.; Anderson, W.B. Production of immunoreactive calcitonin and parathyroid hormone by embryonal carcinoma cells: Alteration with retinoic acid-induced differentiation. Dev. Biol. 1984, 104, 406-412.

156. Levine, R.A.; Campisi, J.; Wang, S.Y.; Gudas, L.J. Butyrate inhibits the retinoic acid-induced differentiation of f9 teratocarcinoma stem cells. Dev. Biol. 1984, 105, 443-450.

157. Miki, K.; Sugimoto, E.; Kitagawa, Y. Reversible interconversion between primitive endodermand parietal endoderm-like 99 cells demonstrated by mrnas expression. J. Biochem. 1987, 102, 385-392.

158. Hadadeh, O.; Barruet, E.; Peiretti, F.; Verdier, M.; Bernot, D.; Hadjal, Y.; Yazidi, C.E.; Robaglia-Schlupp, A.; de Paula, A.M.; Negre, D.; et al. The plasminogen activation system modulates differently adipogenesis and myogenesis of embryonic stem cells. PLoS ONE 2012, 7 , e49065.

159. Solter, D.; Shevinsky, L.; Knowles, B.B.; Strickland, S. The induction of antigenic changes in a teratocarcinoma stem cell line (f9) by retinoic acid. Dev. Biol. 1979, 70, 515-521.

160. Grover, A.; Oshima, R.G.; Adamson, E.D. Epithelial layer formation in differentiating aggregates of $\mathrm{f} 9$ embryonal carcinoma cells. J. Cell Biol. 1983, 96, 1690-1696.

161. Dziadek, M.; Adamson, E. Localization and synthesis of alphafoetoprotein in post-implantation mouse embryos. J. Embryol. Exp. Morphol. 1978, 43, 289-313.

162. Harris, T.M.; Childs, G. Global gene expression patterns during differentiation of $\mathrm{f} 9$ embryonal carcinoma cells into parietal endoderm. Funct. Integr. Genomics 2002, 2, 105-119.

163. Sangster-Guity, N.; Yu, L.M.; McCormick, P. Molecular profiling of embryonal carcinoma cells following retinoic acid or histone deacetylase inhibitor treatment. Cancer Biol. Ther. 2004, 3, 1109-1120.

164. Eifert, C.; Sangster-Guity, N.; Yu, L.-M.; Chittur, S.V.; Perez, A.V.; Tine, J.A.; McCormick, P.J. Global gene expression profiles associated with retinoic acid-induced differentiation of embryonal carcinoma cells. Mo. Reprod. Dev. 2006, 73, 796-824. 
165. Wang, S.Y.; LaRosa, G.J.; Gudas, L.J. Molecular cloning of gene sequences transcriptionally regulated by retinoic acid and dibutyryl cyclic amp in cultured mouse teratocarcinoma cells. Dev. Biol. 1985, 107, 75-86.

166. Soprano, D.R.; Teets, B.W.; Soprano, K.J. Role of retinoic acid in the differentiation of embryonal carcinoma and embryonic stem cells. Vitam. Horm. 2007, 75, 69-95.

167. Alonso, A.; Breuer, B.; Steuer, B.; Fischer, J. The F9-EC cell line as a model for the analysis of differentiation. Int. J. Dev. Biol. 1991, 35, 389-397.

168. Su, D.; Gudas, L.J. Gene expression profiling elucidates a specific role for rargamma in the retinoic acid-induced differentiation of $\mathrm{f} 9$ teratocarcinoma stem cells. Biochem. Pharmacol. 2008, 75, 1129-1160.

169. Astigiano, S.; Sherman, M.I.; Abarzua, P. Regulation and patterns of endogenous and exogenous gene expression during differentiation of embryonal carcinoma cells. Environ. Health Perspect 1989, 80, 25-38.

170. Rogers, M.B.; Watkins, S.C.; Gudas, L.J. Gene expression in visceral endoderm: A comparison of mutant and wild-type 19 embryonal carcinoma cell differentiation. J. Cell Biol. 1990, 110, 1767-1777.

171. Ikuma, S.; Kiyota, M.; Setoyama, C.; Shimada, K. Isolation and characterization of the cdnas corresponding to mrnas abundant in undifferentiated mouse embryonal teratocarcinoma stem cells, but not in differentiated mouse parietal endoderm cells. J. Biochem. 1986, 100, 1185-1192.

172. Sleigh, M.J. Gene expression and differentiation in $\mathrm{f} 9$ mouse embryonal carcinoma cells. Biochem. Soc. Symp. 1989, 55, 1-12.

173. Hu, L.; Gudas, L.J. Cyclic amp analogs and retinoic acid influence the expression of retinoic acid receptor alpha, beta, and gamma mrnas in $\mathrm{f} 9$ teratocarcinoma cells. Mol. Cell. Biol. 1990, 10, 391-396.

174. Boylan, J.F.; Lufkin, T.; Achkar, C.C.; Taneja, R.; Chambon, P.; Gudas, L.J. Targeted disruption of retinoic acid receptor alpha (rar alpha) and rar gamma results in receptor-specific alterations in retinoic acid-mediated differentiation and retinoic acid metabolism. Mol. Cell. Biol. 1995, 15, 843-851.

175. Mendoza-Parra, M.A.; Walia, M.; Sankar, M.; Gronemeyer, H. Dissecting the retinoid-induced differentiation of $\mathrm{f} 9$ embryonal stem cells by integrative genomics. Mol. Syst. Biol. 2011, 7, 538.

176. Young, P.R.; Tilghman, S.M. Induction of alpha-fetoprotein synthesis in differentiating f9 teratocarcinoma cells is accompanied by a genome-wide loss of DNA methylation. Mol. Cell. Biol. 1984, 4, 898-907.

177. Gudas, L.J. Retinoids induce stem cell differentiation via epigenetic changes. Semin. Cell. Dev. Biol. 2013, 24, 701-705.

178. Casanova, J.E.; Grabel, L.B. The role of cell interactions in the differentiation of teratocarcinoma-derived parietal and visceral endoderm. Dev. Biol. 1988, 129, 124-139.

179. LaMonica, K.; Bass, M.; Grabel, L. The planar cell polarity pathway directs parietal endoderm migration. Dev. Biol. 2009, 330, 44-53.

180. Wiles, M.V. Isolation of differentially expressed human cdna clones: Similarities between mouse and human embryonal carcinoma cell differentiation. Development 1988, 104, 403-413. 
181. Chuykin, I.; Schulz, H.; Guan, K.; Bader, M. Activation of the pthrp/adenylate cyclase pathway promotes differentiation of rat xen cells into parietal endoderm, whereas wnt/beta-catenin signaling promotes differentiation into visceral endoderm. J. Cell Sci. 2013, 126, 128-138.

182. Moerkamp, A.T.; Paca, A.; Goumans, M.J.; Kunath, T.; Kruithof, B.P.; Kruithof-de Julio, M. Extraembryonic endoderm cells as a model of endoderm development. Dev. Growth Differ. 2013, 55, 301-308.

183. Hosler, B.A.; LaRosa, G.J.; Grippo, J.F.; Gudas, L.J. Expression of rex-1, a gene containing zinc finger motifs, is rapidly reduced by retinoic acid in $\mathrm{f} 9$ teratocarcinoma cells. Mol. Cell. Biol. 1989, 9, 5623-5629.

184. Vasios, G.W.; Gold, J.D.; Petkovich, M.; Chambon, P.; Gudas, L.J. A retinoic acid-responsive element is present in the $5^{\prime}$ flanking region of the laminin b1 gene. Proc. Natl. Acad. Sci. USA 1989, 86, 9099-9103.

185. Kogai, T.; Liu, Y.Y.; Richter, L.L.; Mody, K.; Kagechika, H.; Brent, G.A. Retinoic acid induces expression of the thyroid hormone transporter, monocarboxylate transporter 8 (mct8). J. Biol. Chem. 2010, 285, 27279-27288.

186. Smith, E.R.; Capo-chichi, C.D.; He, J.; Smedberg, J.L.; Yang, D.H.; Prowse, A.H.; Godwin, A.K.; Hamilton, T.C.; Xu, X.X. Disabled-2 mediates c-fos suppression and the cell growth regulatory activity of retinoic acid in embryonic carcinoma cells. J Biol. Chem. 2001, 276, 47303-47310.

187. Cho, S.Y.; Cho, S.Y.; Lee, S.H.; Park, S.S. Differential expression of mouse disabled 2 gene in retinoic acid-treated 19 embryonal carcinoma cells and early mouse embryos. Mol. Cells 1999, 9 , 179-184.

188. Karperien, M.; Farih-Sips, H.; Hendriks, J.A.; Lanske, B.; Papapoulos, S.E.; Abou-Samra, A.B.; Löwik, C.W.; Defize, L.H. Identification of a retinoic acid-inducible element in the murine pth/pthrp (parathyroid hormone/parathyroid hormone-related peptide) receptor gene. Mol. Endocrinol. 1999, 13, 1183-1196.

189. Verheijen, M.H.; Wolthuis, R.M.; Bos, J.L.; Defize, L.H. The ras/erk pathway induces primitive endoderm but prevents parietal endoderm differentiation of 19 embryonal carcinoma cells. $J$. Biol. Chem. 1999, 274, 1487-1494.

190. Chan, S.D.; Strewler, G.J.; King, K.L.; Nissenson, R.A. Expression of a parathyroid hormone-like protein and its receptor during differentiation of embryonal carcinoma cells. Mol. Endocrinol. 1990, 4, 638-646.

191. Van de Stolpe, A.; Karperien, M.; Lowik, C.W.; Juppner, H.; Segre, G.V.; Abou-Samra, A.B.; de Laat, S.W.; Defize, L.H. Parathyroid hormone-related peptide as an endogenous inducer of parietal endoderm differentiation. J. Cell Biol. 1993, 120, 235-243.

192. Vilardaga, J.P.; Romero, G.; Friedman, P.A.; Gardella, T.J. Molecular basis of parathyroid hormone receptor signaling and trafficking: A family b gpcr paradigm. Cell. Mol. Life Sci. 2011, $68,1-13$.

193. Smedberg, J.L.; Smith, E.R.; Capo-Chichi, C.D.; Frolov, A.; Yang, D.H.; Godwin, A.K.; $\mathrm{Xu}, \mathrm{X} . \mathrm{X}$. Ras/mapk pathway confers basement membrane dependence upon endoderm differentiation of embryonic carcinoma cells. J. Biol. Chem. 2002, 277, 40911-40918. 
194. Smith, E.R.; Smedberg, J.L.; Rula, M.E.; Hamilton, T.C.; Xu, X.X. Disassociation of mapk activation and c-fos expression in $\mathrm{f} 9$ embryonic carcinoma cells following retinoic acid-induced endoderm differentiation. J. Biol. Chem. 2001, 276, 32094-32100.

195. Karperien, M.; van Dijk, T.B.; Hoeijmakers, T.; Cremers, F.; Abou-Samra, A.B.; Boonstra, J.; de Laat, S.W.; Defize, L.H. Expression pattern of parathyroid hormone/parathyroid hormone related peptide receptor mrna in mouse postimplantation embryos indicates involvement in multiple developmental processes. Mech. Dev. 1994, 47, 29-42.

196. Karperien, M.; Lanser, P.; de Laat, S.W.; Boonstra, J.; Defize, L.H. Parathyroid hormone related peptide mrna expression during murine postimplantation development: Evidence for involvement in multiple differentiation processes. Int. J. Dev. Biol. 1996, 40, 599-608.

197. Verheijen, M.H.; Defize, L.H. Signals governing extraembryonic endoderm formation in the mouse: Involvement of the type 1 parathyroid hormone-related peptide (pthrp) receptor, p21ras and cell adhesion molecules. Int. J. Dev. Biol. 1999, 43, 711-721.

198. Yoshida-Koide, U.; Matsuda, T.; Saikawa, K.; Nakanuma, Y.; Yokota, T.; Asashima, M.; Koide, $\mathrm{H}$. Involvement of ras in extraembryonic endoderm differentiation of embryonic stem cells. Biochem. Biophys. Res. Commun. 2004, 313, 475-481.

199. Veltmaat, J.M.; Orelio, C.C.; Ward-van Oostwaard, D.; van Rooijen, M.A.; Mummery, C.L.; Defize, L.H. Snail is an immediate early target gene of parathyroid hormone related peptide signaling in parietal endoderm formation. Int. J. Dev. Biol. 2000, 44, 297-307.

200. Doble, B.W.; Woodgett, J.R. Role of glycogen synthase kinase-3 in cell fate and epithelial-mesenchymal transitions. Cells Tissues Organs 2007, 185, 73-84.

201. Krawetz, R.; Kelly, G.M. Coordinate G $\alpha 13$ and Wnt6- $\beta$-catenin signaling in F9 embryonal carcinoma cells is required for primitive endoderm differentiation. Biochem. Cell Biol. 2009, 87, 567-580.

202. Krawetz, R.; MacKenzie, M.J.; Sun, Q.; Walton, P.A.; Kelly, G.M. Galpha13 activation rescues moesin-depletion induced apoptosis in F9 teratocarcinoma cells. Exp. Cell Res. 2006, 312, 3224-3240.

203. Krawetz, R.J.; Taiani, J.; Greene, A.; Kelly, G.M.; Rancourt, D.E. Inhibition of rho kinase regulates specification of early differentiation events in P19 embryonal carcinoma stem cells. PLoS ONE 2011, 6, e26484.

204. Jho, E.H.; Davis, R.J.; Malbon, C.C. C-jun amino-terminal kinase is regulated by galpha12/galpha13 and obligate for differentiation of p19 embryonal carcinoma cells by retinoic acid. J. Biol. Chem. 1997, 272, 24468-24474.

205. Kanungo, J.; Wang, H.Y.; Malbon, C.C. Ku80 is required but not sufficient for galpha13-mediated endodermal differentiation in p19 embryonic carcinoma cells. Biochem. Biophys. Res. Commun. 2004, 323, 293-298.

206. Lee, Y.N.; Malbon, C.C.; Wang, H.Y. G alpha 13 signals via p115rhogef cascades regulating jnk1 and primitive endoderm formation. J. Biol. Chem. 2004, 279, 54896-54904.

207. Wang, H.Y.; Kanungo, J.; Malbon, C.C. Expression of galpha 13 (q2261) induces p19 stem cells to primitive endoderm via mekk1, 2, or 4. J. Biol. Chem. 2002, 277, 3530-3536. 
208. Bikkavilli, R.K.; Feigin, M.E.; Malbon, C.C. P38 mitogen-activated protein kinase regulates canonical wnt-beta-catenin signaling by inactivation of gsk3beta. J. Cell Sci. 2008, 121, 3598-3607.

209. Inoue, A.; Nagafuchi, A.; Kikuchi, A. Retinoic acid induces discrete wnt-signaling-dependent differentiation in $\mathrm{f} 9$ cells. Biochem. Biophys. Res. Commun. 2009, 390, 564-569.

210. Lin, G.; Zhao, L.; Yin, F.; Lan, R.; Li, L.; Zhang, X.; Zhang, H.; Yang, B. Tcf3 inhibits f9 embryonal carcinoma growth by the down-regulation of oct4. Oncol. Rep. 2011, 26, 893-899.

211. Sandieson, L.; Hwang, J.T.; Kelly, G.M. Redox regulation of canonical Wnt signaling affects extraembryonic endoderm formation. Stem Cells Dev. 2014, 23, 1037-1049.

212. Shibamoto, S.; Winer, J.; Williams, M.; Polakis, P. A blockade in wnt signaling is activated following the differentiation of $\mathrm{f} 9$ teratocarcinoma cells. Exp. Cell Res. 2004, 292, 11-20.

213. Jiang, Y.; Prunier, C.; Howe, P.H. The inhibitory effects of disabled-2 (dab2) on wnt signaling are mediated through axin. Oncogene 2008, 27, 1865-1875.

214. Arceci, R.J.; King, A.A.; Simon, M.C.; Orkin, S.H.; Wilson, D.B. Mouse gata-4: A retinoic acid-inducible gata-binding transcription factor expressed in endodermally derived tissues and heart. Mol. Cell. Biol. 1993, 13, 2235-2246.

215. Koutsourakis, M.; Langeveld, A.; Patient, R.; Beddington, R.; Grosveld, F. The transcription factor gata6 is essential for early extraembryonic development. Development 1999, 126, 723-732.

216. Shimoda, M.; Kanai-Azuma, M.; Hara, K.; Miyazaki, S.; Kanai, Y.; Monden, M.; Miyazaki, J. Sox17 plays a substantial role in late-stage differentiation of the extraembryonic endoderm in vitro. J. Cell Sci. 2007, 120, 3859-3869.

217. Qu, X.B.; Pan, J.; Zhang, C.; Huang, S.Y. Sox17 facilitates the differentiation of mouse embryonic stem cells into primitive and definitive endoderm in vitro. Dev. Growth Differ. 2008, 50, 585-593.

218. Niakan, K.K.; Ji, H.; Maehr, R.; Vokes, S.A.; Rodolfa, K.T.; Sherwood, R.I.; Yamaki, M.; Dimos, J.T.; Chen, A.E.; Melton, D.A.; et al. Sox17 promotes differentiation in mouse embryonic stem cells by directly regulating extraembryonic gene expression and indirectly antagonizing self-renewal. Genes Dev. 2010, 24, 312-326.

219. Seguin, C.A.; Draper, J.S.; Nagy, A.; Rossant, J. Establishment of endoderm progenitors by sox transcription factor expression in human embryonic stem cells. Cell Stem Cell 2008, 3, 182-195.

220. Futaki, S.; Hayashi, Y.; Emoto, T.; Weber, C.N.; Sekiguchi, K. Sox7 plays crucial roles in parietal endoderm differentiation in $\mathrm{f} 9$ embryonal carcinoma cells through regulating gata-4 and gata-6 expression. Mol. Cell. Biol. 2004, 24, 10492-10503.

221. Barbacci, E.; Reber, M.; Ott, M.O.; Breillat, C.; Huetz, F.; Cereghini, S. Variant hepatocyte nuclear factor 1 is required for visceral endoderm specification. Development 1999, 126, 4795-4805.

222. Jacob, A.; Budhiraja, S.; Qian, X.; Clevidence, D.; Costa, R.H.; Reichel, R.R. Retinoic acid-mediated activation of hnf-3 alpha during ec stem cell differentiation. Nucleic Acids Res. 1994, 22, 2126-2133.

223. Reichel, R.R.; Budhiraja, S.; Jacob, A. Delayed activation of hnf-3 beta upon retinoic acid-induced teratocarcinoma cell differentiation. Exp. Cell Res. 1994, 214, 634-641. 
224. Chen, W.S.; Manova, K.; Weinstein, D.C.; Duncan, S.A.; Plump, A.S.; Prezioso, V.R.; Bachvarova, R.F.; Darnell, J.E., Jr. Disruption of the hnf-4 gene, expressed in visceral endoderm, leads to cell death in embryonic ectoderm and impaired gastrulation of mouse embryos. Genes Dev. 1994, 8, 2466-2477.

225. Cho, S.Y.; Jeon, J.W.; Lee, S.H.; Park, S.S. P67 isoform of mouse disabled 2 protein acts as a transcriptional activator during the differentiation of F9 cells. Biochem. J. 2000, 352 Pt 3, 645-650.

226. Kim, J.A.; Bae, S.H.; Choi, Y.J.; Kim, K.H.; Park, S.S. Feed-back regulation of disabled-2 (dab2) p96 isoform for gata-4 during differentiation of $\mathrm{f} 9$ cells. Biochem. Biophys. Res. Commun. 2012, 421, 591-598.

227. Sherwood, R.I.; Jitianu, C.; Cleaver, O.; Shaywitz, D.A.; Lamenzo, J.O.; Chen, A.E.; Golub, T.R.; Melton, D.A. Prospective isolation and global gene expression analysis of definitive and visceral endoderm. Dev. Biol. 2007, 304, 541-555.

228. Morrisey, E.E.; Tang, Z.; Sigrist, K.; Lu, M.M.; Jiang, F.; Ip, H.S.; Parmacek, M.S. Gata6 regulates hnf4 and is required for differentiation of visceral endoderm in the mouse embryo. Genes Dev. 1998, 12, 3579-3590.

229. Hwang, J.T.K.; Kelly, G.M. Gata6 and Foxa2 regulate Wnt6 expression during extraembryonic endoderm formation. Stem Cells Dev. 2012, 21, 3220-3232.

230. Lewis, S.L.; Tam, P.P. Definitive endoderm of the mouse embryo: Formation, cell fates, and morphogenetic function. Dev. Dyn. 2006, 235, 2315-2329.

231. Tam, P.P.; Kanai-Azuma, M.; Kanai, Y. Early endoderm development in vertebrates: Lineage differentiation and morphogenetic function. Curr. Opin. Genet. Dev. 2003, 13, 393-400.

232. Kunath, T.; Arnaud, D.; Uy, G.D.; Okamoto, I.; Chureau, C.; Yamanaka, Y.; Heard, E.; Gardner, R.L.; Avner, P.; Rossant, J. Imprinted x-inactivation in extra-embryonic endoderm cell lines from mouse blastocysts. Development 2005, 132, 1649-1661.

233. Rossant, J. Stem cells and lineage development in the mammalian blastocyst. Reprod. Fertil. Dev. 2007, 19, 111-118.

234. Shimosato, D.; Shiki, M.; Niwa, H. Extra-embryonic endoderm cells derived from es cells induced by gata factors acquire the character of xen cells. BMC Dev. Biol. 2007, 7, 80.

235. Cho, L.T.; Wamaitha, S.E.; Tsai, I.J.; Artus, J.; Sherwood, R.I.; Pedersen, R.A.; Hadjantonakis, A.K.; Niakan, K.K. Conversion from mouse embryonic to extra-embryonic endoderm stem cells reveals distinct differentiation capacities of pluripotent stem cell states. Development 2012, 139, 2866-2877.

236. Brown, K.; Legros, S.; Artus, J.; Doss, M.X.; Khanin, R.; Hadjantonakis, A.K.; Foley, A. A comparative analysis of extra-embryonic endoderm cell lines. PLoS One 2010, 5, e12016.

237. Senner, C.E.; Krueger, F.; Oxley, D.; Andrews, S.; Hemberger, M. DNA methylation profiles define stem cell identity and reveal a tight embryonic-extraembryonic lineage boundary. Stem Cells 2012, 30, 2732-2745.

238. Kraus, M.R.; Grapin-Botton, A. Patterning and shaping the endoderm in vivo and in culture. Curr. Opin. Genetics Dev. 2012, 22, 347-353. 
239. Pagliuca, F.W.; Millman, J.R.; Gurtler, M.; Segel, M.; van Dervort, A.; Ryu, J.H.; Peterson, Q.P.; Greiner, D.; Melton, D.A. Generation of functional human pancreatic beta cells in vitro. Cell 2014, 159, 428-439.

240. Rezania, A.; Bruin, J.E.; Arora, P.; Rubin, A.; Batushansky, I.; Asadi, A.; O’Dwyer, S.; Quiskamp, N.; Mojibian, M.; Albrecht, T.; et al. Reversal of diabetes with insulin-producing cells derived in vitro from human pluripotent stem cells. Nat. Biotechnol. 2014, 32, 1121-1133.

241. Cho, K.W.; Kwon, H.J.; Shin, J.O.; Lee, J.M.; Cho, S.W.; Tickle, C.; Jung, H.S. Retinoic acid signaling and the initiation of mammary gland development. Dev. Biol. 2012, 365, 259-266.

242. Frenz, D.A.; Liu, W.; Cvekl, A.; Xie, Q.; Wassef, L.; Quadro, L.; Niederreither, K.; Maconochie, M.; Shanske, A. Retinoid signaling in inner ear development: A "goldilocks" phenomenon. Am. J. Med. Genetics. A 2010, 152A, 2947-2961.

(C) 2015 by the authors; licensee MDPI, Basel, Switzerland. This article is an open access article distributed under the terms and conditions of the Creative Commons Attribution license (http://creativecommons.org/licenses/by/4.0/). 